\title{
A Felony, I Presume? 21 USC § 841(b)’s Mitigating Provision and the Categorical Approach in Immigration Proceedings
}

\author{
Laura Jean Eichten $\dagger$
}

\section{INTRODUCTION}

Imagine two immigrants: Sven and Ole. They have both previously-at "T1" - been convicted of a crime under state law. Sven was convicted of battery and Ole of possession of marijuana with intent to distribute. Both pleaded guilty, and their respective records of conviction contain few facts describing the precise circumstances of their crimes. Sven's record does not mention any details-such as whether his battery was negligent or intentional-and he pleaded to a sentence of less than one year. Ole's record indicates neither the drug quantity nor whether he was intending to sell the marijuana or merely give it to a friend. For both, these crimes were committed years ago. Both are lawful permanent residents who have built a life in the United States, married US citizens, and could have filed the application to become US citizens themselves.

Now - at "T2" - both have been arrested by immigration officials. ${ }^{1}$ While both are deemed deportable, ${ }^{2}$ Sven and Ole both have

$\dagger$ BA 2009, Michigan State University; JD Candidate 2013, The University of Chicago Law School.

1 There are many reasons noncitizens, including lawful permanent residents, might come on the radar of immigration officials. For instance, when applying for citizenship, offenses such as mistakenly registering to vote while obtaining a driver's license can lead to removal proceedings. See William R. Yates, Deputy Executive Associate Commissioner, US Dept of Justice, Memorandum For All Regional Directors, District Directors, Service Center Directors, Officers-in-Charge, Procedures for Handling Naturalization Applications of Aliens Who Voted Unlawfully or Falsely Represented Themselves as U.S. Citizens by Voting or Registering to Vote (May 7, 2002), online at http://www.uscis.gov/USCIS/Laws/Memoranda/VoterMem _Plus86.pdf (visited Sept 19, 2012); 8 USC § 1227(a)(6)(A). Immigration officials could similarly be notified if a background check run after the application's submission reveals previously unknown crimes. Another common way to be picked up by immigration officials today is through the Secure Communities program. See generally Secure Communities, http://www.ice.gov/secure_communities (visited Sept 19, 2012); Shadi Masri, Current Development, ICE's Initiation of Secure Communities Draws More Criticism than Praise, 25 Georgetown Immig L J 533 (2011).

2 Even immigrants who have achieved "lawful permanent resident" status might still be deported at any time if, for example, they are found to have made certain misrepresentations 
the opportunity to apply for cancellation of removal as long as their previous crimes are not considered "aggravated felonies." Both an intentional battery conviction with a sentence of over one year and possession of more than a small amount of marijuana with intent to distribute for remuneration are considered aggravated felonies. ${ }^{3}$

For Sven, proving his eligibility for cancellation of removal will not be terribly problematic. The immigration judge will look at his conviction of battery - which encompasses conduct that is both negligent and intentional-and presume that Sven did not commit a crime of violence, which requires a mens rea greater than negligence. ${ }^{4}$ Even though it is possible that Sven had the appropriate mens rea for a crime of violence, the court will not presume the higher mens rea. And because negligent battery is not an aggravated felony, Sven will remain eligible for cancellation of removal.

Ole might not be so lucky. Some courts will not presume that Ole committed the version of this offense carrying the lowest penalty but will instead presume that Ole had more than a "small amount" of marijuana that he intended to distribute for remuneration. Unless his record of conviction clearly states otherwise, Ole will have to introduce extra evidence regarding his $\mathrm{T} 1$ offense to prove that he actually possessed only a small amount of marijuana and that he did not intend to distribute it for remuneration. Otherwise, the judge will find that he has committed an aggravated felony, and Ole will be ineligible for cancellation of removal. But obtaining evidence regarding his $\mathrm{T} 1$ conviction will likely be impossible if too much time has passed. Further, it is not clear that an immigration judge would be equipped to hear evidence regarding the circumstances of Ole's T1 offense.

The difference between Sven and Ole arises because of the difficulties in translating state law offenses into federal law. Immigration law defines the category of aggravated felony and often does so with reference to federal crimes as defined in the United States Code. But Sven and Ole-like most criminal defendants in this country-were convicted of state law offenses. ${ }^{5}$ Yet state and federal law frequently

or committed an aggravated felony, a crime involving moral turpitude, or marriage fraud. See 8 USC $\$ 1227$.

3 See Leocal v Ashcroft, 543 US 1, 8-12 (2004).

4 See id.

5 Compare Sean Rosenmerkel, Matthew Durose, and Donald Farole Jr, Felony Sentences in State Courts, 2006-Statistical Tables 1 (US Dept of Justice, Bureau of Statistics Dec 2009), online at http://bjs.ojp.usdoj.gov/content/pub/pdf/fssc06st.pdf (visited Sept 19, 2012) (estimating that $1,132,290$ people were sentenced by state courts for a felony conviction in 2006), with Administrative Office of the United States Courts, Judicial Business of the United States Courts: 2010 Annual Report of the Director 242 table D-4 (2010), online at http://www.uscourts 
use different factors in determining the severity of a crime, making it difficult to identify federal analogues to state crimes. Thus the fates of Sven and Ole depend on the translation of their state law offenses into federal offenses - they will remain eligible for cancellation of removal only if the state law crimes are translated into federal crimes that are not aggravated felonies. This process of translating state law convictions into a federal law category is generally governed by what is known as a "categorical approach." It is both highly technical and the subject of numerous circuit splits.

This Comment discusses one category of crimes that constitutes an aggravated felony: felony drug crimes under the federal Controlled Substances Act ${ }^{6}$ (CSA). Recently, federal circuit courts have split on what to do when a state law drug offense, like the one Ole was convicted of, is written broadly enough to include conduct that, had the charges been brought under federal law, might have been punished as only a misdemeanor under 21 USC $\S 841(\mathrm{~b})(4)$. The difficulty arises because $\S 841$ (b)(4) is a mitigating provision, as opposed to an element of the crime, and therefore criminal defendants are sentenced under the felony provision by default. In other words, defendants tried under federal law are required to produce evidence in order to obtain the benefit of the misdemeanor provision. This creates a problem in $\mathrm{T} 2$ immigration proceedings in which the noncitizen's record includes a $\mathrm{T} 1$ state law drug conviction: in his $\mathrm{T} 1$ trial, the noncitizen might not have had any reason (or opportunity) to provide the evidence that would have entitled him to a misdemeanor sentence had he been tried in federal court. This problem has created a split regarding the proper treatment of $\mathrm{T} 1$ state law drug convictions during $\mathrm{T} 2$ immigration proceedings.

Some courts in this circuit split are more concerned with limiting immigration judges' ability to engage in fact finding years after a noncitizen's original state law conviction. This concern leads these courts to presume that the $\mathrm{T} 1$ state law conviction corresponds to the federal misdemeanor provision when assessed during a T2 immigration proceeding.'

Other circuits focus more on limiting inconsistencies between criminal sentencing and immigration law. Inconsistencies arise where the same crime would be presumed a felony in federal criminal

.gov/uscourts/Statistics/JudicialBusiness/2010/JudicialBusinespdfversion.pdf (visited Sept 19, 2012) (providing that 89,741 criminal defendants were convicted and sentenced in US District Courts in 2010).

6 Pub L No 91-513, 84 Stat 1242 (1970), codified as amended at 21 USC $\$ 801$ et seq.

7 See, for example, Martinez v Mukasey, 551 F3d 113, 122 (2d Cir 2008); Jeune v Attorney General, 476 F3d 199, 203-04 (3d Cir 2007). 
sentencing and a misdemeanor in an immigration proceeding. In light of this concern, this group of courts presumes that the state law conviction corresponds to the federal felony provision. ${ }^{8}$

As technical as this issue is, it is important to keep in mind that it is of great importance to many noncitizens. As the Supreme Court has noted with some alarm, reforms in the last few decades have made " $[t]$ he 'drastic measure' of deportation or removal . . . virtually inevitable for a vast number of noncitizens convicted of crimes." Aggravated felonies bar a noncitizen not only from applying for cancellation of removal but also from applying for asylum. ${ }^{10}$ They also can bar an applicant from applying for withholding of removal." These are generally seen as the final humanitarian relief options available to noncitizens before deportation to a country that might persecute or torture them.

This Comment comprises four parts. Part I provides an overview of the immigration law on cancellation of removal and the challenges in defining "aggravated felony." It includes a detailed discussion of the approaches for dealing with the translation of state law convictions into federal crimes. Part II explains the intricacies of the CSA, which, as will be seen in Part III, further complicate the already complicated process of defining an aggravated felony. Part III delves into the circuit split concerning how courts should analogize state law drug convictions to the misdemeanor provision in the CSA, 18 USC $\$ 841(\mathrm{~b})(4)$.

Finally, Part IV proposes a framework for translating state law drug convictions into federal drug convictions under $\$ 841(\mathrm{~b})(4)$. It argues that the circuit courts addressing this issue have failed to give adequate attention to the Supreme Court's guidance regarding the categorical approach, as well as the original reasons for using the categorical approach in immigration proceedings. This guidance suggests that courts should analyze crimes differently during collateral proceedings at $\mathrm{T} 2$ than if they were adjudicating criminal sentencing proceedings at T1. The framework adopted by this Comment allows the immigration judge to look into the record of conviction under

8 See, for example, Julce v Mukasey, 530 F3d 30, 35 (1st Cir 2008); Garcia v Holder, 638 F3d 511, 517 (6th Cir 2011), petition for cert filed, 80 USLW 3058 (July 18, 2011); Moncrieffe v Holder, 662 F3d 387, 392 (5th Cir 2011), cert granted 132 S Ct 1857 (2012).

9 Padilla v Kentucky, 130 S Ct 1473, 1478 (2010), quoting Fong Haw Tan v Phelan, 333 US 6,10 (1948).

10 See 8 USC $\$ 1158(\mathrm{~b})(2)(\mathrm{B})(\mathrm{i})$.

11 See, for example, In re Y-L-, 23 INS Dec 270, 270-71 (BIA 2002) (holding that individuals who have committed aggravated felonies are eligible for withholding of removal "only under the most extenuating circumstances that are both extraordinary and compelling"). 
broad statutes to the extent he can find facts that were necessarily decided by the $\mathrm{T} 1$ fact finder. But on an empty record-a criminal trial record that indicates neither the quantity nor remunerative nature of the drug transaction-this Comment suggests that state law drug convictions should be presumed to correspond to the CSA's misdemeanor provision, and thus the noncitizen should be presumed not to have committed an aggravated felony.

\section{BACKGROUND}

\section{A. Deportation and Cancellation of Removal Generally}

Noncitizens-even those who are here legally, such as lawful permanent residents-face the possibility of deportation when they commit certain crimes. Section 212 of the Immigration and Nationality $\mathrm{Act}^{12}$ (INA) details the criminal offense categories that subject a noncitizen to the possibility of deportation. ${ }^{13}$ These include certain drug-related crimes, crimes deemed aggravated felonies, and many other general categories of crimes that Congress has designated. ${ }^{14}$ These crimes might even be accidental, such as mistakenly registering to vote..$^{15}$

Even if a noncitizen is deportable, however, he can still argue for various forms of statutory relief. One such form of relief, cancellation of removal for certain lawfully admitted permanent residents, ${ }^{16}$ is at issue in the circuit split on which this Comment focuses. To qualify for cancellation of removal under 8 USC $\$ 1229 \mathrm{~b}(\mathrm{a})$, a noncitizen must prove he has (1) "been an alien lawfully admitted for permanent residence for not less than 5 years," (2) "resided in the United States continuously for 7 years after having been admitted in any status," and (3) "not been convicted of any aggravated felony." As it is the noncitizen who is applying for cancellation of removal, it is up to him to meet the burden of proving that each

\footnotetext{
12 Pub L No 82-414, 66 Stat 163 (1952), codified as amended at 8 USC $\$ 1101$ et seq.

13 See Immigration Act of $1990 \S 602$, Pub L No 101-649, 104 Stat 4978, 5077-82, codified as amended at $8 \mathrm{USC} \S 1227$ (a).

14 See 8 USC $\$ 1227(a)(2)$.

15 See note 1.

$168 \mathrm{USC} \S 1229 \mathrm{~b}(\mathrm{a})$. There is another provision in $8 \mathrm{USC} \S 1229 \mathrm{~b}$ for nonpermanent residents to apply for cancellation of removal, but this provision is not at issue in this Comment. See 8 USC $\$ 1229 b(b)$.

178 USC $\$ 1229 \mathrm{~b}(\mathrm{a})$. Note that an aggravated felony also bars relief under the type of cancellation of removal that is available to nonpermanent residents. See 8 USC $\S 1229 \mathrm{~b}(\mathrm{~b})(1)(\mathrm{C})$ (limiting relief under subsection (b) to individuals not convicted of an offense under 8 USC $\$ 1227(\mathrm{a})(2)$ ); 8 USC $\$ 1227$ (a)(2)(A)(iii) (rendering deportable any individual who has been convicted of an aggravated felony after admission).
} 
element is met. ${ }^{18}$ Even if all elements are met, immigration judges still have discretion to deny relief - the statutory elements are necessary but not sufficient for cancellation of removal. ${ }^{19}$ Much of the litigation concerning cancellation of removal has revolved around the precise meaning of aggravated felony, which is the question at issue in this Comment.

The INA defines aggravated felony to include a number of categories and types of crimes. ${ }^{20}$ Relevant to this Comment's inquiry, these include certain drug crimes defined in the CSA. Specifically, these include crimes involving "illicit trafficking in a controlled substance (as defined in section 802 of title 21), including a drug trafficking crime (as defined in section 924(c) of title 18). ${ }^{\prime 21}$ The INA further specifies that the term aggravated felony "applies to an offense ... whether in violation of Federal or State law."'2 But the INA gives little guidance on how to determine if and when a state conviction meets this definition, so it has been left to the courts to fill in the gaps. Given the numerous circuit splits regarding the precise definition of aggravated felony, ${ }^{23}$ it should be no surprise that another circuit split has arisen in this context.

\section{B. The Categorical Approach}

The categorical approach is a crucial aspect of immigration proceedings generally. Its application in the determination of whether a noncitizen has committed an aggravated felony is no exception. The term "categorical approach" describes the general approach courts take at $\mathrm{T} 2$ in translating a conviction from a $\mathrm{T} 1$ proceeding $-\mathrm{a}$ conviction under the state statute of conviction. This T1 statute of conviction is translated into the offense described in the defining statute at issue in the $\mathrm{T} 2$ proceeding. This process might occur years or even decades after the original conviction.

18 See, for example, Sandoval-Lua v Gonzales, 499 F3d 1121, 1123 (9th Cir 2007).

19 See 8 USC $\$ 1229 b(a)$. See also 8 USC $\S 1252(a)(1)(B)(i)$ (listing cancellation of removal under 8 USC $\$ 1229 \mathrm{~b}$ as a form of "discretionary relief" not generally subject to judicial review).

20 See 8 USC $\$ 1101$ (a)(43). Note that the definition of aggravated felony is not specific to cancellation of removal but rather applies to a number of provisions in the immigration code. See, for example, note 10 and accompanying text.

218 USC $\$ 1101(a)(43)(B)$. These sections are part of the CSA.

228 USC $\$ 1101(\mathrm{a})(43)$.

23 See generally Natalie Liem, Note, Mean What You Say, Say What You Mean: Defining the Aggravated Felony Deportation Grounds to Target More than Aggravated Felons, $59 \mathrm{U}$ Fla L Rev 1071 (2007) (providing a summary of the multiple circuit splits arising from attempts to define "aggravated felony" and arguing for a revision of the statute to make it more internally consistent and easier to uniformly apply). 
The categorical approach is a two-step process:

(1) Determine the elements of the crime as defined in the defining statute.

(2) Decide if the statute of conviction necessarily requires those elements to have been proved in the criminal's T1 proceeding (with some variations authorizing a look into the record of conviction to determine if all elements were present).

This approach can be understood as an alternative to a factual approach, whereby a T2 judge would take a fresh look into the facts and events of the underlying crime (perhaps even hearing new evidence to that effect) and determine for himself whether the exact conduct of the defendant fits the defining statute.

1. Beginnings of the categorical approach.

The categorical approach was first applied in the immigration context in 1914 in United States $v U h l^{4}$ - a case still cited to support the use of the categorical approach in immigration proceedings and whose articulation of the approach is still consistently followed. ${ }^{25} \mathrm{Uhl}$ concerned a noncitizen seeking admission into the United States (at T2). He had previously been convicted of a crime in England (at T1) and could have been denied entry had his $\mathrm{T} 1$ conviction been deemed a "crime involving moral turpitude." The $U h l$ court held that, in determining whether a noncitizen has been convicted of a crime involving moral turpitude for the purposes of immigration law, the judge must look at the record of conviction and not at "the testimony adduced at the trial." 27 That is, a judge's inquiry into the nature of the offense must be confined to looking at the judgment; the court cannot take a fresh look at the evidence itself. ${ }^{28}$ Thus, the court limited itself to those aspects of the crime that were necessary for the conviction-refusing to consider those aspects that were only potentially at issue in the $\mathrm{T} 1$ trial. The court provided a colorful illustration of this limitation:

\footnotetext{
$24 \quad 210$ F 860 (2d Cir 1914).

25 See, for example, Fajardo v United States, 659 F3d 1303, 1307-09 (11th Cir 2011) (noting the principles established in $U h l$ and further noting the "considerable level of agreement, spanning several decades and across various amendments to the national immigration law" that supports still using this approach).

$26 \mathrm{Uhl}, 210 \mathrm{~F}$ at 862.

27 Id at 863.

28 Id.
} 
A statute of the United States (Rev. St. \$ 2139) makes it a crime to give a glass of whisky to an Indian under the charge of an Indian agent. A conviction under this section would not be proof of moral turpitude, although the evidence at the trial might disclose the fact that the whisky was given for the basest purposes. ${ }^{29}$

Uhl also set forth some basic principles behind its limitation on the inquiry that a $\mathrm{T} 2$ court can undertake. First, it reasoned from the particular capacity of immigration judges: immigration officers, the Uhl court held, "act in an administrative capacity," so they should "not act as judges of the facts." Second, the court stressed, as a related concern, the importance of efficient adjudication - a goal that could not be met if immigration courts undertook in-depth inquiries into the precise facts of past convictions. ${ }^{31}$ Third, the $U h l$ court held that, to prevent injustice, the law must be uniformly administered upon broad "general lines." 32 In other words, if two noncitizens are convicted of the same crime, one should not be excluded from the country because his trial was more involved and included evidence suggesting moral turpitude, while the other's trial record was empty (if, for example, he pleaded guilty).$^{33}$ This rationale undergirded the court's holding that a $\mathrm{T} 2$ finding of moral turpitude should be limited to those crimes where the statute of conviction's elements alone established moral turpitude. ${ }^{34}$

Importantly, the $U h l$ court saw the limitation to the original elements of conviction as applying to both the government and the noncitizen. The court explicitly rejected the idea that noncitizens should have the opportunity (or burden) during a $\mathrm{T} 2$ proceeding to show facts that depart from their actual T1 convictions:

$[\mathrm{T}]$ he rule which confines the proof of the nature of the offense to the judgment is clearly in the interest of a uniform and efficient administration of the law and in the interest of the immigration officials as well, for if they may examine the testimony on the trial to determine the character of the offense, so may the immigrant. How could the law be speedily and efficiently administered

\footnotetext{
29 Id at 862 . The $U h l$ court's limitation to what is necessarily decided mirrors the requirement that an issue have been decided in order to have res judicata effect in a subsequent proceeding. See, for example, Russell v Place, 94 US 606, 608-09 (1876).

$30 \mathrm{Uhl}, 210 \mathrm{~F}$ at 863 . See also Fajardo, $659 \mathrm{~F} 3 \mathrm{~d}$ at 1308, citing Howes $v$ Tozer, $3 \mathrm{~F} 2 \mathrm{~d} 849$, 852 (1st Cir 1925).

$31 U h l, 210 \mathrm{~F}$ at 862 .

32 Id at 863 .

33 See id at 862-63.

34 Id.
} 
if an immigrant convicted of perjury, burglary or murder, is permitted to show from the evidence taken at the trial that he did not commit a felony, but a misdemeanor only? ? $^{35}$

2. The categorical approach's modern revival in sentencing.

a) Taylor and the categorical approach. More recently, the categorical approach was revitalized in a series of Supreme Court cases dealing with sentencing enhancements. ${ }^{36}$ Specifically, the $\mathrm{Ca}-$ reer Criminals Amendment Act of $1986^{37}$ provides a sentence enhancement for a defendant "who has three prior convictions for specified types of offenses." ${ }^{38}$ For these types of crimes, such as burglary or a crime of violence, the Supreme Court has determined that Congress meant the "generic" version of these crimes. In other words, the definition is not to vary depending on the state statute of conviction. Instead, the offense is to be defined by the common, generally accepted elements of the crime. ${ }^{39}$ These cases dealt with how to determine whether a criminal convicted under a state statute at $\mathrm{T} 1$ would be deemed at $\mathrm{T} 2$ to have committed the generic crime.

The first case was Taylor $v$ United States, ${ }^{40}$ where the Supreme Court held "that an offense constitutes 'burglary' for purposes of a $\S 924$ (e) sentence enhancement if either its statutory definition substantially corresponds to 'generic' burglary, or the charging paper and jury instructions actually required the jury to find all the elements of generic burglary in order to convict the defendant." ${ }^{.41}$ Specifically, the Taylor Court held that the inquiry for the T2 court is whether the statutory offense had all of the elements of burglary because only then does "the conviction necessarily impl[y] that the defendant has been found guilty of all the elements of generic burglary." ${ }^{42}$ Note that, as a general rule, the inquiry the Taylor Court sets forth involves nothing specific to the particular defendant: once one knows a defendant's state law statute of conviction and the crime to which it is to be compared, it is simply a matter of aligning the elements.

$35 U h l, 210 \mathrm{~F}$ at $862-63$.

36 See, for example, Taylor $v$ United States, 495 US 575, 600 (1990); Shepard $v$ United States, 544 US 13, 17 (2005).

37 Anti-Drug Abuse Act of $1986 \$ \$ 1401-02$, Pub L No 99-570, 100 Stat 3207, 3207-39 to -40 , codified at 18 USC $\$ 924(\mathrm{e})$.

38 Taylor, 495 US at 577-78.

39 Id at 602.

40495 US 575 (1990).

41 Id at 602.

42 Id at 599 (emphasis added). 
The Taylor Court did, however, permit consideration of the individual facts at issue in a particular conviction in certain limited circumstances. If a state statute of conviction is written broadly, so that a specific conviction might or might not have been based on all of the elements of generic burglary, a court can go beyond the mere fact of conviction and look at what the jury necessarily had to find to convict. ${ }^{43}$ Echoing Uhl's admonition, however, the Court limited this inquiry to the "narrow range of cases where a jury was actually required to find all the elements of generic burglary."

The Court provided an example of a case in which a court might look into the record of conviction. Having established that burglary requires "entry into, or remaining in, a building or structure," Court went on to note that:

[I]n a State whose burglary statutes include entry of an automobile as well as a building, if the indictment or information and jury instructions show that the defendant was charged only with a burglary of a building, and that the jury necessarily had to find an entry of a building to convict, then the Government should be allowed to use the conviction for enhancement. ${ }^{46}$

The Court justified its holding by pointing out the "practical difficulties and potential unfairness of a factual approach." ${ }^{{ }^{47} 7}$ That is, the Court did not want $\mathrm{T} 2$ courts to entirely reevaluate the facts of a defendant's $\mathrm{T} 1$ case; at most, it permitted a limited inquiry into the record of conviction. The Court also pointed to congressional intent to support its holding: "If Congress had meant to adopt an approach that would require the sentencing court to engage in an elaborate factfinding process regarding the defendant's prior offenses, surely this would have been mentioned somewhere in the legislative history." ${ }^{348}$

b) Shepard's affirmation of Taylor's categorical approach. The Court reaffirmed Taylor's holding in Shepard $v$ United States ${ }^{49}$ and further specified the permissible scope of the inquiry into a defendant's T1 record of conviction to determine whether it "necessarily admitted elements of the generic offense." ${ }^{" 0}$ The Court held that such an inquiry "is limited to the terms of the charging document,

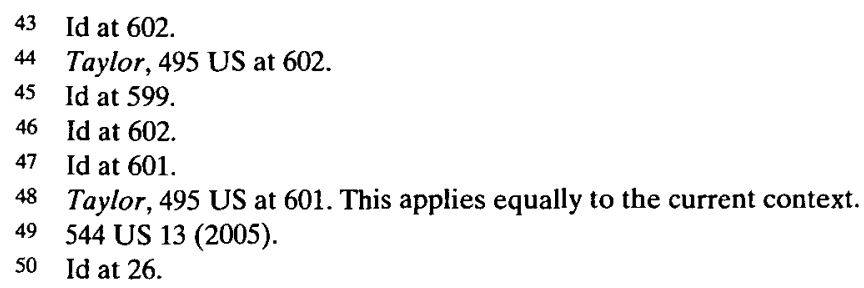


the terms of a plea agreement or transcript of colloquy between judge and defendant in which the factual basis for the plea was confirmed by the defendant, or to some comparable judicial record of this information." that is, the limitation on the factual inquiries at $T 2$ to prevent independent weighing of the evidence by the $\mathrm{T} 2$ judge - was at the "heart of the decision" in Taylor. ${ }^{.2}$

c) Constitutional issues potentially implicated by Taylor and Shepard. A plurality of the Court buttressed its holdings in the Shepard and Taylor cases by pointing to Sixth and Fourteenth Amendment concerns-specifically the right to a trial by jury, which has tremendous implications in cases dealing with criminal sentencing, such as Shepard and Taylor. Such concerns, as the Shepard Court noted, require any factual decisions that might increase the "ceiling of a potential sentence"-including those relating to the T1 conviction - to be submitted to the jury..$^{53}$

3. Shepard and Taylor in the immigration context.

Recent Supreme Court cases have also applied the TaylorShepard line of reasoning to immigration cases. It was first applied to aggravated felony cases most like those in Taylor and Shepard, where the categories of aggravated felonies were described in generic terms such as burglary offenses or crimes of violence. Starting in Leocal $v$ Ashcroft ${ }^{54}$ in which the offense in question was described as a "crime of violence," the Court held that the analysis should focus, as in Taylor and Shepard, on the "offense of conviction." In other words, courts are required "to look to the elements and the nature of the offense of conviction, rather than to the particular facts relating to [the] petitioner's crime." ${ }^{\text {s6 }}$ This is not to say that this guidance has been uniformly applied. Within the immigration context, the

51 Id.

52 See id at 23. An important part of this reasoning was that fifteen years later, the Court had to assume Congress relied on the Taylor decision in making subsequent amendments to the INA, and that it chose not to modify Taylor's use of the categorical approach in the statute. Id.

53 Shepard, 544 US at 25 (Souter) (plurality). This reasoning can be seen as giving weight to the Court's holding in Apprendi v New Jersey, 530 US 466 (2000). See notes 92-103 and accompanying text.

54543 US 1 (2004).

55 Id at 7.

56 Id. Later, the Court explicitly applied the Taylor-Shepard line of reasoning to a case where the aggravated felony of theft was at issue. See Gonzales v Duenas-Alvarez, 549 US 183, 185-86 (2007) (noting that the lower courts had uniformly used this approach when "determining whether a conviction ... falls within the scope of a listed offense"). 
categorical approach has been interpreted in a variety of ways by lower courts. ${ }^{57}$

\section{THE CONTROLLED SUBSTANCES ACT AND THE CATEGORICAL APPROACH}

As mentioned above, another category of offenses that qualifies as an aggravated felony - the category that is particularly relevant to this Comment -includes state law offenses that would constitute a felony under the CSA (which is the T2 statute to which state laws will be compared for the rest of this Comment's discussion). ${ }^{58}$ This Part attempts to accomplish two goals regarding this category of offenses: First, Part II.A discusses the key Supreme Court cases that have used the categorical approach in immigration cases that grapple with the CSA. Second, Part II.B turns to a peculiar provision in the CSA, $\S 841$ (b), and explains some of the underlying complexities in $\mathrm{T} 1$ applications of this provision. This background, as will be shown, is immensely important in understanding the root of the issue in the immigration circuit split.

\section{A. Supreme Court Cases Applying the Categorical Approach to the CSA}

While still following the basics of the categorical approach as applied in the Taylor-Shepard line of cases, the Supreme Court has prescribed a slightly different (or perhaps simply more specific) test when the aggravated felony definition points not to a generic offense but to conduct specifically defined in another federal provision. ${ }^{59}$

57 For a more detailed explanation of the ways the categorical approach has been applied in immigration courts and potential ways the analysis could be used, see Rebecca Sharpless, Toward a True Elements Test: Taylor and the Categorical Analysis of Crimes in Immigration Law, 62 U Miami L Rev 979, 989-90 (2008) (noting four potential interpretations of the categorical approach: (1) "adjudicators are precluded from ever looking beyond the statute of conviction"; (2) "adjudicators can look to reliable documents, but can only rely on facts that were necessarily decided (facts that established elements) in the criminal proceedings"; (3) "immigration adjudicators are permitted to look to enumerated, reliable documents related to the criminal conviction, but can rely on any uncontradicted fact in those documents"; or (4) "give immigration adjudicators unfettered authority to adjudicate all facts underlying the conviction," and also noting that courts only follow the middle approaches).

58 See 18 USC $\$ 802$ et seq; 8 USC $\$ 1101(\mathrm{a})(43)$.

59 See, for example, 8 USC $\S 1101(a)(43)$ (defining "aggravated felony" as including "illicit trafficking in a controlled substance ... including a drug trafficking crime (as defined in section 924(c) of title 18)"); 18 USC $\$ 924$ (c)(2) ("For purposes of this subsection, the term "drug trafficking crime" means any felony punishable under the Controlled Substances Act."). 


\section{Lopez v Gonzales.}

The Court's approach for translating state law convictions to statutorily defined federal crimes, deemed the hypothetical federal felony rule by the lower courts, was developed in Lopez $v$ Gonzales. ${ }^{.0}$ In Lopez, the defendant was convicted of an offense that was a felony under state law but a misdemeanor under the federal CSA. The Court adopted an $U h l$-like approach, holding that a noncitizen's T1 conviction under state law is considered an aggravated felony for purposes of immigration law only if the state offense "proscribes conduct punishable as a felony" under the CSA." The Court specifically refused to adopt an approach that would look to whether the $\mathrm{T} 1$ crime was classified as a misdemeanor or a felony under the state statute of conviction. ${ }^{62}$

Importantly, the Court reasoned that the Government's argument was against the "commonsense conception of 'illicit trafficking,' the term ultimately being defined." ${ }^{63}$ Because "trafficking" is not defined in the relevant statutes, the Court reasoned that the "everyday understanding" and "regular usage" of the term would show "what Congress probably meant." And, it held, in everyday meaning, trafficking ordinarily "means some sort of commercial dealing." The Court found that "[r]eading $\$ 924$ (c) the Government's way, then, would often turn simple possession into trafficking, just what the English language tells us not to expect, and that result makes us very wary of the Government's position."'s

To get to this holding, the Lopez Court relied in large part on legislative intent, noting that, "if Congress had meant us to [adopt the state's classification of the statute of conviction] it would have found a much less misleading way to make its point. ${ }^{167}$ Further, since Congress specifically referred to a federal statute, it would be odd if "Congress meant to allow the States to supplant its own classifications when it specifically constructed its immigration law to turn on them. ${ }^{\prime 68}$ Beyond legislative intent, the Court also noted that using a categorical-type approach leads to more uniformity than relying on state law classifications.

60549 US 47 (2006).

61 Id at 60.

62 Id at 55.

63 Id at 53.

64 Lopez, 549 US at 54.

65 Id at 53.

66 Id at 54.

67 Id at 55.

68 Lopez, 549 US at 60. 


\section{Carachuri-Rosendo v Holder.}

The Lopez holding could be interpreted as departing from the Taylor-Shepard line of reasoning, in that it instructs courts to look at the defendant's "conduct" as opposed to the "elements" of the statutes of conviction, and by focusing on whether such conduct was "punishable as a felony." While this language was intended to render the particular classification of a crime under state law (as either a felony or a misdemeanor) irrelevant, it resulted in substantial variance in the application of the Lopez rule by the circuit courts. ${ }^{70}$ In 2010, after confusion arose in the lower courts, the Supreme Court readdressed the Lopez holding in Carachuri-Rosendo v Holder ${ }^{11}$ and clarified the Lopez approach as falling more squarely in line with the Taylor-Shepard line of cases.

Carachuri-Rosendo was a repeat offender of very minor drug offenses-his most recent charge was for possessing one prescription pill without a prescription. ${ }^{2}$ As a repeat offender, he could have been convicted of a felony under the CSA. The Texas prosecutors, however, chose not to seek any enhancement based on his prior offenses, and so under Texas law he was only convicted of a misdemeanor. ${ }^{73}$ Thus, while Texas law has a similar repeat offender enhancement, his record of conviction "contain[ed] no finding of the fact of his prior drug offense." ${ }^{\prime 4}$

The lower courts held that because "Carachuri-Rosendo's 'conduct' could have been prosecuted as simple possession with a recidivist enhancement under state law-even though it was not-it... was an 'aggravated felony' for immigration law purposes." 75 That is, the lower courts considered Carachuri-Rosendo as having been convicted of a "hypothetical felony"-essentially speculating as to how his $\mathrm{T} 1$ conviction would have come out had this evidence been introduced and used in the trial, even though it was not introduced.

The Court rejected this argument, holding that the inquiry at $\mathrm{T} 2$ "cannot, ex post, enhance the state offense of record just because facts known to it would have authorized a greater penalty under state or federal law."' The relevant inquiry, the Court held, is not

69 Id.

70 For a more in-depth description of this circuit split, see Part III. See also notes 106-08 and accompanying text.

$71 \quad 130 \mathrm{~S} \mathrm{Ct} 2577$ (2010).

72 Id at 2580.

73 Id at 2580-84.

74 Id at 2586.

75 Carachuri-Rosendo, $130 \mathrm{~S} \mathrm{Ct}$ at 2584.

76 Id at 2586. 
whether Carachuri-Rosendo "could have been charged with a federal felony," but whether "the "proscribe[d] conduct' of a state offense ... is 'punishable as a felony under that federal law." ${ }^{\prime 78}$ Here the possession of a single pill, the conduct proscribed by state law, would not be a federal felony. As this Comment argues, this clarification has important ramifications for this circuit split. ${ }^{79}$

The crux of the Court's logic was that important procedural safeguards would be lacking were it to accept the Government's argument. Specifically, the Court noted that criminal defendants would be entitled to certain procedural safeguards if the Government were attempting to charge them as recidivists: "Notice, plus an opportunity to challenge the validity of the prior conviction used to enhance the current conviction, [under 21 USC] $\$ \S 851$ (b)-(c), are mandatory prerequisites to obtaining a punishment based on the fact of a prior conviction." ${ }^{" 10}$ And because Carachuri-Rosendo had not been charged as a recidivist during his $\mathrm{T} 1$ conviction, he had not received any such procedural safeguards. Thus, he could not later be considered to have committed a felony, even if the same procedural safeguards were provided to him at T2. Among other things, applying the recidivist enhancement at $\mathrm{T} 2$ would have undermined the discretion given to the state prosecutor. ${ }^{81}$ Thus, the Court specifically rejected the Government's contention that such notice procedures and prosecutorial discretion were "meaningless, so long as they may be satisfied during the immigration proceeding," holding that "these procedural requirements have great practical significance with respect to the conviction itself and are integral to the structure and design of our drug laws."

The Court also took pains to note that, as in Lopez, CarachuriRosendo's case first needed to be analyzed under the "commonsense conception" of the statutory terms. ${ }^{83}$ That is, the Court essentially applied the plain meaning rule of statutory construction. ${ }^{84}$ The conduct here-simple possession of one prescription pill-did not strike

77 Id.

78 Id at 2588 (alteration in original) (emphasis added), quoting Lopez, 549 US at 60.

79 See Part IV.

80 Carachuri-Rosendo, $130 \mathrm{~S} \mathrm{Ct}$ at 2582.

81 See id at 2587-88.

82 Id.

83 Id at 2585 (quotation marks omitted), quoting Lopez, 549 US at 53.

84 For a discussion of the usage of the plain meaning rule in statutory interpretation, see William N. Eskridge Jr, The New Textualism, 37 UCLA L Rev 621, 626-30, 652-55 (1990). 
the Court as falling within the "commonsense conception" of drug trafficking. ${ }^{\text {.s }}$

Finally, the Court also noted that "ambiguities in criminal statutes referenced in immigration laws should be construed in the noncitizen's favor." ${ }^{\text {sh }}$ As will become clear later, these rationales constitute a vital part of this Comment's solution.

\section{B. The Peculiarity of 21 USC $\S 841(\mathrm{~b})$}

One specific provision of the CSA has been the source of confusion and debate in criminal sentencing as well as immigration and is key to the immediate circuit split. As mentioned earlier, the aggravated felony category at issue in this circuit split is the category defined as "illicit trafficking in a controlled substance (as defined in section 802 of title 21), including a drug trafficking crime (as defined in section 924(c) of title 18)." ${ }^{\prime 87}$ Turning to 18 USC $\$ 924(\mathrm{c})$, a drug trafficking crime is defined as "any felony punishable under the Controlled Substances Act." ${ }^{\text {"*8 }}$

One of the main provisions of the CSA is 21 USC $\$ 841$ (a), relating to the common crime of drug possession. This provision makes it unlawful "to manufacture, distribute, or dispense, or possess with intent to manufacture, distribute, or dispense, a controlled substance; or [] to create, distribute, or dispense, or possess with intent to distribute or dispense, a counterfeit substance." ${ }^{\prime \prime g}$

The degree of punishment for the offense, as determined by $\S 841$ (b), is based on the quantity and type of drug implicated, as well as whether the transaction was for remuneration. The key distinction in the statute, for our purposes, is between $\S 841(\mathrm{~b})(1)(\mathrm{D})$ and $\S 841$ (b)(4). Under $\S 841$ (b)(1)(D) it is a felony to possess with intent to deliver less than fifty kilograms of marijuana: "In the case of less than 50 kilograms of marihuana, ... such person shall, except as provided in paragraphs (4) and (5) of this subsection, be sentenced to a term of imprisonment of not more than 5 years." $\%$ However, $\S 841$ (b)(4) provides an exception: "Notwithstanding paragraph (1)(D) of this subsection, any person who violates subsection (a) of this section by distributing a small amount of marihuana for no remuneration" is punished as if the crime were only simple possession,

\footnotetext{
85 Carachuri-Rosendo, $130 \mathrm{~S} \mathrm{Ct}$ at 2585.

86 Id at 2589.

878 USC $\$ 1101(\mathrm{a})(43)(\mathrm{B})$.

8818 USC $\S 924(\mathrm{c})(2)$.

8921 USC $\$ 841(\mathrm{a})$.

9021 USC $\$ 841(b)(1)(D)$.
} 
which is a misdemeanor." The $\S 841(\mathrm{~b})(4)$ exception would apply, for example, in a situation where someone intends to give, but not sell, a small quantity of drugs to a friend.

The Supreme Court's holding in Apprendi v New Jersey ${ }^{92}$ provides some key guidance for interpreting criminal statutes like this one. There, the Supreme Court held that any fact (other than the existence of a prior conviction) that increases the penalty for a crime beyond the statutory maximum must be submitted to a jury and proved beyond a reasonable doubt. ${ }^{93}$

Since Apprendi there has been some debate as to how $\S 841$ (b) should be applied at T1, when the offender is initially sentenced. Specifically, there is a circuit split regarding whether drug quantity is an element of $\S 841(\mathrm{~b}) .^{94}$ The Second, Fourth, Fifth, Ninth, Tenth, and DC Circuits have held that "because the maximum potential sentence to which a defendant is exposed increases as the amount of drugs in question does," drug quantity is an element. ${ }^{* 6}$ The First, Third, Sixth, Seventh, and Eighth Circuits have disagreed and held that drug quantity is not an element of the offense. ${ }^{97}$ As Lindsay Calkins has suggested, those circuits that hold drug quantity is an element of the crime would "expand the scope of Apprendi," while those that do not would "substantially limit Apprendi's applicability." This underlying circuit split has parallels in the immigration circuit split discussed below.

The outcome of the circuit split over whether drug quantity is an element of $\$ 841$ (b), however, is tangential to the circuit split at issue in this Comment. When there has been no drug quantity determined (as in the cases in the immigration circuit split), all of the circuit courts that have confronted the issue agree that $\$ 841(\mathrm{~b})(1)(\mathrm{D})$ is the baseline in the sentencing phase, even for cases in which the jury did

9121 USC \$ 841(b)(4).

92530 US $466(2000)$.

93 Id at 491.

94 See Lindsay Calkins, Comment, Is Drug Quantity an Element of 21 USC $\$ 841(b)$ ? Determining the Apprendi Statutory Maximum, 78 U Chi L Rev 965, 966-67 (2011).

95 Id at 966.

96 See United States v Gonzalez, 420 F3d 111, 123, 133-34 (2d Cir 2005); United States v Promise, 255 F3d 150, 156-57 (4th Cir 2001); United States v Doggett, 230 F3d 160, 164-65 (5th Cir 2000); United States v Velasco-Heredia, 319 F3d 1080, 1085 (9th Cir 2003); United States $v$ Hishaw, 235 F3d 565, 575 (10th Cir 2000); United States v Fields, 242 F3d 393, 395-96 (DC Cir 2001).

97 See United States v Goodine, 326 F3d 26, 27-28 (1st Cir 2003); United States v Vazquez, 271 F3d 93, 98 (3d Cir 2001); United States v Franco, 484 F3d 347, 356-57 (6th Cir 2007); United States $v$ Leachman, 309 F3d 377, 383 (6th Cir 2002); United States v Clark, 538 F3d 803, 812 (7th Cir 2008); United States $v$ Serrano-Lopez, 366 F3d 628, 638 n 9 (8th Cir 2004).

98 Calkins, Comment, $78 \mathrm{U}$ Chi L Rev at 966 (cited in note 94). 
not determine the quantity of marijuana." These courts have reasoned that the proper default provision should be "the one which states a complete crime upon the fewest facts" not "the provision with the lowest penalty."100

Central to these courts' holdings is the fact that Apprendi's procedural safeguards are not triggered by a mitigating provision such as $\S 841(\mathrm{~b})(1)(\mathrm{D})$. The Second Circuit, for example, reasoned that while Apprendi held that "any fact that increases the penalty for a crime beyond the prescribed statutory maximum must be submitted to a jury,"101 the converse statement also follows. Thus, "any fact that decreases the penalty for a crime need not be so treated." ${ }^{\prime 102}$ The court thus reasoned that "[i]f a fact increases that punishment, it must be treated as an offense element; otherwise, it need not be."103 And since $\S 841$ (b)(1)(D) does not increase the punishment, the underlying facts could remain unproven to the jury, with the defendant bearing the burden of proof at the sentencing phase. That is why even those circuits holding that drug quantity is an element of the offense in certain circumstances have found that it is not an element of the offense for purposes of $\S 841(\mathrm{~b})(1)(\mathrm{D})$.

These T1 holdings regarding $\S 841$ (b) become substantial obstacles in the immigration circuit split discussed below, as many courts are tempted to draw an analogy between the requirements in a T1 federal criminal sentencing and a $\mathrm{T} 2$ immigration proceeding.

\section{THE IMMIGRATION SPLIT}

The circuit split in the immigration context deals with the problem of applying T1 holdings from the federal criminal sentencing context, such as Apprendi, to T2 immigration proceedings, in which the categorical approach typically applies. As mentioned earlier, a

99 See, for example, United States v Outen, 286 F3d 622, 638 (2d Cir 2002); United States v Bartholomew, 310 F3d 912, 926 (6th Cir 2002) (agreeing with Outen's reasoning in a case where the defendant's crime could not have been considered a misdemeanor under $\$ 841(\mathrm{~b})(4)$ because at trial there was overwhelming evidence that the quantity of drugs was twenty-eight pounds); United States $v$ Walker, 302 F3d 322, 324-25 (5th Cir 2002) (finding that since the defendant's "sentence does not exceed the statutory maximum for that provision, there is no $A p$. prendi error"); United States v Hamlin, 319 F3d 666, 670-71 (4th Cir 2003) ("Clearly $\S 841(\mathrm{~b})(1)(\mathrm{D})$ is the baseline provision because it states a complete crime upon the fewest facts. Section $841(\mathrm{~b})(4)$ is a mitigating exception to the five-year statutory maximum found in $\$ 841$ (b)(1)(D). [Especially since] Apprendi recognized that the existence of possible facts in mitigation does not affect the statutory maximum.") (quotation marks omitted).

100 Outen, 286 F3d at 638.

101 Id, quoting Apprendi, 530 US at 490.

102 Outen, 286 F3d at 638.

103 Id. 
noncitizen defendant who is deportable and wishes to remain eligible for cancellation of removal will need to prove that he did not commit an aggravated felony. Such a felony includes "illicit trafficking in a controlled substance ... including a drug trafficking crime." Unlike the CSA, however, which has the $\$ 841(b)(4)$ remunerationmisdemeanor exception, most state statutes of conviction are written broadly and do not have provisions similar to $\S 841(\mathrm{~b})(4)$-nor do these statutes even mention remuneration.

The central problem, then, is that there is a legitimate claim that the conduct at issue in these state law convictions correlates to either a felony or a misdemeanor under the CSA. Such ambiguity is not typically the case under the categorical approach because, with the run-of-the-mill criminal statute, an additional fact must be proved to increase the severity of a crime to a felony, and the approach works simply and easily to require definitive proof of that additional fact. Thus, to return to the example of Sven, the existence of evidence, such as a weapon, might turn a battery conviction into an offense for which the term of imprisonment is at least one year. Courts universally hold that the form of the offense without the extra evidence is the "baseline" provision and that, absent a specific $\mathrm{T} 1$ conviction involving the extra evidence (or a necessary finding of that evidence at the $\mathrm{T} 1$ proceeding), it is clear that no aggravated felony has been committed. ${ }^{105}$ Because the misdemeanor provision in the CSA is a mitigating factor that requires additional proof (at least at a T1 sentencing hearing) to lessen the severity of a crime, however, it is not clear how the categorical approach applies to identify the proper federal correlate.

The question is essentially whether the court will presume, when a noncitizen defendant's conviction record is empty, that he would have fallen into the mitigating provision-a contrary presumption will frequently foreclose any possibility of a noncitizen remaining in the country, no matter how sympathetic his case. The First, Fifth, and Sixth Circuits have found that, as in a T1 federal criminal sentencing proceeding, the defendant bears the burden of proving he would have fallen into the mitigating provision had he been convicted under federal law. ${ }^{106}$ The Second Circuit, on an empty record, would place no such burden on the noncitizen defendant but rather

1048 USC $\$ 1101(a)(43)(B)$

105 See, for example, Leocal, 543 US at 11-12.

106 See Julce v Mukasey, 530 F3d 30, 35 (1st Cir 2008); Moncrieffe v Holder, 662 F3d 387, 392 (5th Cir 2011), cert granted 132 S Ct 1857 (2012); Garcia v Holder, 638 F3d 511, 517 (6th Cir 2011), petition for cert filed, 80 USLW 3058 (July 18, 2011). 
would apply $\S 841(\mathrm{~b})(4) .{ }^{107}$ The Third Circuit takes a middle approach on how to use the categorical approach but on an empty record would also presume the $\S 841$ (b)(4) exception applies. ${ }^{108}$

A. A Felony until Proved Otherwise: Making the Defendant Rebut the Felony Presumption

The First, Fifth, and Sixth Circuits essentially follow their criminal sentencing holdings in determining how $\S 841(\mathrm{~b})(4)$ applies in the immigration context. The First Circuit decided this issue in Julce $v$ Mukasey, ${ }^{109}$ holding that $\S 841$ (b)(1)(D), the felony provision, is the default provision in immigration proceedings. ${ }^{110}$ In Garcia $v$ Holder ${ }^{111}$ the Sixth Circuit similarly held that the baseline presumption in immigration proceedings is $\S 841$ (b)(1)(D) - in effect, establishing a presumption that prior convictions under broadly written state drug trafficking laws constitute aggravated felonies. ${ }^{112}$ In Moncrieffe $v$ Holder, ${ }^{113}$ the Fifth Circuit, the most recent court to weigh in on the split, expressed its agreement with the holdings of the First and Sixth Circuits. ${ }^{114}$

In all three cases, the noncitizen defendant had been convicted under a state law for possession of marijuana with intent to distribute. ${ }^{115}$ The courts all found that the elements of the state statutes of conviction qualified as an aggravated felony because the elements corresponded to $\S 841$ (b)(1)(D). ${ }^{116}$ The Julce court noted, however, that "the state marijuana statute encompasses conduct that would not be punishable as a felony under the CSA," but rather as a misdemeanor under $\S 841(b)(4){ }^{.11}$

\footnotetext{
107 See Martinez v Mukasey, 551 F3d 113, 122 (2d Cir 2008).

108 See Jeune v Attorney General, 476 F3d 199, 203 (3d Cir 2007).

109530 F3d 30 (1st Cir 2008).

110 Id at 35 .

111638 F3d 511 (6th Cir 2011), petition for cert filed, 80 USLW 3058 (July 18, 2011).

112 Id at 517

113662 F3d 387 (5th Cir 2011), cert granted 132 S Ct 1857 (2012).

114 Id at 392.

115 In Julce, the conviction was under Mass Gen Laws Ann ch 94C, \& 32C(a) (prohibiting the manufacture, distribution, dispensation, or cultivation of certain substances and providing a statutory maximum of two years imprisonment). In Garcia, the conviction was under Mich Comp Laws $\$ 333.7401(2)(d)(i i i)$ (punishing marijuana possession "if the amount is less than 5 kilograms or fewer than 20 plants, by imprisonment for not more than 4 years or a fine of not more than $\$ 20,000.00$ or both"). In Moncrieffe, the conviction was under Ga Code Ann $\S 16-$ 13-30(j) (making it a crime to possess, control, manufacture, deliver, distribute, dispense, sell, or purchase marijuana, with no reference to quantity).

116 See Julce, 530 F3d at 33, citing Berhe v Gonzales, 464 F3d 74, 84-85 (1st Cir 2006); Garcia, 638 F3d at 516; Moncrieffe, 662 F3d at 392.

117 Julce, 530 F3d at 33-34.
} 
The courts held that a noncitizen defendant must explicitly prove his conduct would have fallen into the $\S 841(b)(4)$ exception and that, as a baseline presumption, a court would assume that the noncitizen's prior crime constituted an aggravated felony. The courts all justified their holdings by turning to $\mathrm{T} 1$ sentencing cases and noting that all courts to consider the question had found that $\S 841(b)(4)$ "does not create a stand-alone misdemeanor offense," but rather is "best understood as a mitigating sentencing provision." ${ }^{\prime 18}$ The Sixth Circuit, in United States v Bartholomew, ${ }^{119}$ had held (as the Garcia court put it) that "the amount of marihuana need not be proved to convict under $\S 841$ (a) or to punish under $\S 841(\mathrm{~b})(1)(\mathrm{D})$ " and "that $\S 841(\mathrm{~b})(1)(\mathrm{D})$ establishes the default punishment for cases where the amount of marihuana is undetermined." ${ }^{20}$ The Fifth Circuit, in Moncrieffe, also noted its T1 sentencing precedent from United States $v$ Walker, ${ }^{121}$ in which it had held that $\S 841(b)(1)(D)$ was the baseline for criminal sentencing cases at $\mathrm{T} 1 .^{122}$

The Julce court summarized the $\S 841$ (b)(4) mitigating provision as one that was meant to function as a "carve-out" for "defendants guilty of no more than social sharing of marijuana." ${ }^{{ }_{123}}$ Since the defendant in a criminal trial "bears the burden of producing mitigating evidence in order to obtain misdemeanor treatment under $\S 841$ (b)(4)," the court held that the noncitizen defendant should bear this burden in immigration proceedings as well. ${ }^{124}$ Any different rule, the court reasoned, would "create a disparity in the law's use of the analogy to federal criminal statutes." ${ }^{\text {"125 }}$ Thus, the Julce court felt comfortable abandoning the general categorical approach it typically would apply in immigration proceedings given the "nature of this subsection."

At least for the Garcia court, the consistency between immigration and criminal proceedings was so important that it did not even address the contrary application of the categorical approach utilized

118 Id at 35; Garcia, 638 F3d at 516, quoting Julce, 530 F3d at 35; Moncrieffe, 662 F3d at 391, quoting United States v Bartholomew, 310 F3d 912, 925 (6th Cir 2002).

119310 F3d 912 (6th Cir 2002).

120 Garcia, 638 F3d at 518, citing Bartholomew, 310 F3d at 925.

121302 F3d 322 (5th Cir 2002).

122 Id at 324.

123 Julce, 530 F3d at 34, citing Outen, 286 F3d at 637-38.

124 Julce, $530 \mathrm{~F} 3 \mathrm{~d}$ at 35-36.

125 Id at 35.

126 Id at 34 (noting that when a "state statute is written broadly enough to cover at least some non-felonious conduct" the Government can use the facts in the record of conviction to "provide clear and convincing evidence" that the offense constitutes an aggravated felony). 
by the other circuits; it did not even consider whether it could be consistent with Bartholomew, its T1 sentencing precedent. ${ }^{127}$

The Julce court did recognize that it would be difficult for a noncitizen defendant to produce evidence relating to his prior conviction, especially since the noncitizen defendant "not considering the immigration context, may have had no incentive to produce such evidence in the state court proceeding." ${ }^{\prime 28}$ However, the court left the question of whether a noncitizen defendant would even be allowed to introduce evidence not in the record of conviction to the immigration judge. ${ }^{129}$ These complications-inherent in the fact that an immigration judge would be looking back to a conviction he did not hear-were insufficient to cause the court to question its holding. It saw "no reason to adopt a different rule" for the immigration context than for the criminal context. ${ }^{130}$

\section{B. Applying the Misdemeanor Presumption}

The Second and Third Circuits have taken a different view, both holding that $\S 841(\mathrm{~b})(4)$ must be the baseline presumption in immigration proceedings. The Second Circuit has not addressed what it takes to rebut the $\S 841(\mathrm{~b})(4)$ misdemeanor presumption. The Third Circuit, however, has shown it is willing to look into the record for evidence that the noncitizen defendant's T1 crime would have been a felony, as Shepard permits, but seems to view more facts as "necessarily decided" than the phrase implies.

\section{The Second Circuit's reasoning.}

In Martinez $v$ Mukasey, ${ }^{131}$ the noncitizen was convicted of criminal sale of marijuana in the fourth degree,$^{132}$ a misdemeanor violation of New York's drug laws. ${ }^{133}$ The Martinez court held that, in an immigration proceeding, only the minimum conduct necessary to sustain a state law conviction could be assumed, thus rendering $\S 841(b)(4)$ the baseline presumption. ${ }^{134}$

\footnotetext{
127 Garcia, 638 F3d at 517-18.

128 Julce, $530 \mathrm{~F} 3 \mathrm{~d}$ at 36.

129 Id.

130 Id at 35.

131551 F3d 113 (2d Cir 2008).

132 Id at 116.

133 See NY Penal Law $\$ 221.40$ ("A person is guilty of criminal sale of marihuana in the fourth degree when he knowingly and unlawfully sells marihuana [and that] criminal sale of marihuana [is a] misdemeanor.").

134 See Martinez, 551 F3d at 119.
} 
The Martinez court felt its conclusion followed inexorably from applying the categorical approach. Under the Second Circuit's already settled interpretation of the categorical approach, "the singular circumstances of an individual petitioner's crimes should not be considered, and only the minimum criminal conduct necessary to sustain a conviction under a given statute is relevant." since the noncitizen defendant's $\mathrm{T} 1$ state conviction "cover[ed] distribution of very small quantities of marihuana," including "sale of over two grams of marihuana," his "conviction could have been for any form of nonremunerative transfer of as little as two grams of marihuana." ${ }^{136}$ Recognizing that $\S 841(\mathrm{~b})(4)$ covered not only a lesser degree of activity than $\S 841$ (b)(1)(D) but also activity "of a different type more akin to simple possession than to provisions intended to cover traffickers," 137 the court concluded that "[a]s the categorical approach requires, we look no further than to the fact that Martinez's conviction could have been for precisely the sort of nonremunerative transfer of small quantities of marihuana that is only a federal misdemeanor under 21 USC \$ 841(b)(4)."

Unlike the First, Fifth, and Sixth Circuits, the Second Circuit found no need to harmonize its criminal sentencing and immigration precedent on $\S 841$ (b)(4), explicitly refusing to consider such consistency as a factor in its analysis. ${ }^{139}$ Its outcome, the Martinez court held, was compelled by the "[categorical] approach to defining aggravated felonies" in immigration proceedings. ${ }^{140}$

The Martinez court supported its holding by enumerating a number of concerns about the fact that a noncitizen defendant's eligibility for $\S 841(b)(4)$ mitigation would essentially be considered for the first time at T2. Specifically, the court noted that the categorical approach does not typically allow the intensive fact finding by the immigration judge that an approach putting the burden on the noncitizen defendant would require. The court worried that such fact finding would place an enormous strain on the immigration courts, and is a task for which they are entirely ill-suited. ${ }^{141}$ Indeed, the court explicitly rejected this fact finding as fundamentally incompatible

135 Gertsenshteyn v Mukasey, 544 F3d 137, 143 (2d Cir 2008), quoting Dalton v Ashcroft, 257 F3d 200, 204 (2d Cir 2001).

136 Martinez, 551 F3d at 119-20.

137 Id at 120, quoting Outen, 286 F3d at 637

138 Martinez, 551 F3d at 120.

139 Id at 118 ("To the extent that we must define an aggravated felony, that definition need not comport with the definition used outside of the immigration context.").

140 Id.

141 See id at 121-22. 
with the categorical approach: "The very basis of the categorical approach is that the sole ground for determining whether an immigrant was convicted of an aggravated felony is the minimum criminal conduct necessary to sustain a conviction." ${ }^{142}$ Placing the burden on the noncitizen would require looking into the evidence of the actual criminal conduct, which might not have been seen by the initial, T1 court. ${ }^{1{ }^{3} 3}$ This was a result the Martinez court would not sanction.

The Martinez court made a point of distinguishing its prior holding in United States $v$ Simpson. ${ }^{144}$ Simpson addressed an illegal reentry conviction, a crime discussed in detail in Part IV. It involved the same state statute as Martinez, and the court held that a conviction is an aggravated felony for the purposes of sentencing an individual convicted of illegal reentry "when it is: (1) an offense punishable under the CSA, and (2) can be classified as a felony under either state or federal law." ${ }^{145}$ With little analysis of the issue, the Simpson court simply affirmed the holding of the district court that these offenses "would have been punishable as a felony under the CSA" and thus were aggravated felonies. ${ }^{166}$ Essentially, in Simpson, the Second Circuit followed its $\S 841$ (b) criminal sentencing precedent in treating $\S 841(b)(1)(D)$ as the baseline - the same reasoning the First, Fifth, and Sixth Circuits use in immigration proceedings.

The Martinez court felt Simpson was easily distinguishable since it was "only the law of the circuit for cases under the Sentencing Guidelines" and "in no way could-or sought to-overrule the use of the [categorical] approach" in immigration proceedings. ${ }^{147}$ While the holding of the Simpson court might not have been dispositive, its logic certainly parallels that of the First, Fifth, and Sixth Circuits in fixating on the felony provision as the more appropriate correlate given the structure of the mitigating provision.

\section{The Third Circuit's reasoning.}

Similar to the Second Circuit, the Third Circuit, in Jeune $v$ Attorney General, ${ }^{148}$ held that the misdemeanor provision, $\S 841(\mathrm{~b})(4)$, is the baseline presumption in immigration proceedings $\mathrm{s}^{149}-\mathrm{a}$ holding

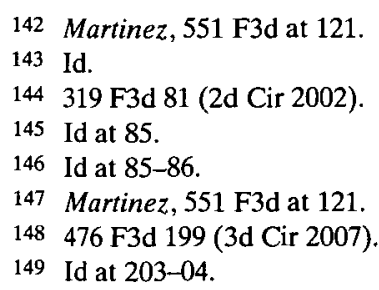


reaffirmed in Evanson $v$ Attorney General. ${ }^{150}$ Thus, on an empty record, the Third Circuit would find that a noncitizen defendant has not committed an aggravated felony when a state drug trafficking law is written broadly enough to include conduct to which $\$ 841(\mathrm{~b})(4)$ would apply had the T1 trial occurred in federal court. While coming to a similar result as the Second Circuit, the Third Circuit's holding and reasoning are somewhat different - and have quite different implications for future application - in that the Third Circuit would allow a thorough look into the $\mathrm{T} 1$ record of conviction for evidence that the specific conviction would not fit into $\S 841(\mathrm{~b})(4)$.

In Jeune, the noncitizen was convicted under state law for the "manufacture, delivery, or possession with intent to manufacture or deliver, a controlled substance." "151 The Jeune court found that it "must rely only on 'what the convicting court must necessarily have found to support the conviction." "152 Since the record of Jeune's conviction did not include how much marijuana he possessed and had "no indication that Jeune was distributing marijuana for money," the court ruled that it had to "assume that Jeune's conduct was only the minimum necessary to comport with the statute and record."153 This reasoning required the court to assume that the $\mathrm{T} 1$ conviction would have only been a federal misdemeanor under $\$ 841(\mathrm{~b})(4)$ and was not considered an aggravated felony for the purposes of the immigration proceedings. The court either did not consider or was untroubled by any potential inconsistencies with criminal sentencing law, as it did not even mention its criminal sentencing precedent in Jeune.

Unlike the Second Circuit, the Third Circuit has confronted a case where it held the $\S 841$ (b)(4) presumption was rebutted by the record of conviction. In Santos $v$ Attorney General, ${ }^{154}$ the Third Circuit directly addressed this issue and found, after looking deep into Santos's T1 criminal record, that he had committed an aggravated felony given the additional information recited at his plea hearing. ${ }^{155}$ At Santos's T1 state court plea hearing for his drug conviction, the prosecutor had recited the facts leading to Santos's arrest, including the fact that Santos was engaged in a drug transaction: "When the state court judge asked Santos whether the facts recited by the

150550 F3d 284 (3d Cir 2008).

$15135 \mathrm{~Pa}$ Cons Stat Ann $\S 780-113(\mathrm{a})(30)$.

152 Jeune, 476 F3d at 205, quoting Steele v Blackman, 236 F3d 130, 135 (3d Cir 2001).

153 Jeune, 476 F3d at 204-05.

154352 Fed Appx 742 (3d Cir 2009).

155 Id at 744 . 
prosecutor were essentially correct, Santos denied that a transaction took place." ${ }^{156}$ Only after conferring with his attorney did Santos agree that the facts were "essentially correct." 157

The court held that this inquiry into the record of the T1 proceeding was appropriate and that the inquiry proved that the noncitizen defendant had in fact been convicted of an aggravated felony, despite the fact that he only agreed to the essential facts and voiced a denial that a transaction took place..$^{158}$ In this case, then, the fact that the court was only authorized to look at what was "necessarily decided" meant it could consider Santos's final acknowledgement of the essential facts, ${ }^{159}$ which is more than many other circuits permit. But, despite Santos's argument that he never admitted to the trafficking element of the crime, the court would not permit further examination of the record for consideration of Santos's initial denial of that same fact during the plea hearing. Thus, while the Third Circuit allows an inquiry only into what is necessarily decided, it seems to take a fairly adaptable view and construes ambiguities in the Government's favor. In an average case, this in-depth inquiry might not matter, but in cases like Santos's it could eliminate all hope of staying in the country. The key analytical question is how much ambiguity there needs to be in the facts, such as in the plea colloquy in Santos's case, before it is no longer necessarily decided.

$$
* * *
$$

In summary, the First, Fifth, and Sixth Circuits place the burden on the noncitizen defendant to prove his conduct would have been punishable as a misdemeanor under federal law and, if this burden is not met, presume that the conduct was a felony. The Second and Third Circuits presume the opposite - that the conduct was a misdemeanor under federal law. The Third Circuit will evidently construe some ambiguities in the noncitizen defendant's $\mathrm{T} 1$ conviction record in favor of the Government in order to conclude that his conduct was a felony.

\footnotetext{
$156 \mathrm{Id}$.

157 Id.

158 Santos, 352 Fed Appx at 744.

159 Id at 744-45.
} 


\section{SOLVING THE SPLIT: What MAKES SENSE FOR IMMIGRATION LAW}

This Comment proposes solving this circuit split by utilizing $\S 841$ (b)(4) as a baseline presumption for an empty record.

This circuit split is riddled with concerns outside the realm of an immigration proceeding itself. The root of the split is that it appears to be impossible both to follow the Supreme Court precedent on approaching bifurcated statutes and to avoid inconsistencies with criminal sentencing cases. The courts in this circuit split have two fundamental points of disagreement:

(1) Whether the baseline for $\S 841$ (b) in a T2 immigration proceeding should be a felony, thus preserving consistency between immigration and other types of proceedings, or a misdemeanor; and

(2) To what extent an immigration judge can look into the T1 record and conduct collateral fact finding at $\mathrm{T} 2$.

This Comment argues that there is a fundamental difference between the way crimes should be analyzed at $\mathrm{T} 1$ (right after the crime took place) and at T2 (in a later immigration proceeding). Sacrificing consistency with criminal sentencing law is the only way for courts to respect Supreme Court precedent while avoiding due process concerns. Just as important, consistency between $\mathrm{T} 1$ criminal proceedings and $\mathrm{T} 2$ immigration proceedings is not necessarily what makes the most sense for immigration proceedings. What does make the most sense is a simple solution-one that is consistent within the realm of immigration law. Specifically, since illegal reentry cases demand using $\$ 841(b)(4)$ as the baseline, consistency between these cases and $\mathrm{T} 2$ immigration proceedings is most important.

Figure 1 helps to illustrate the different proceedings and courts that are at issue. The arrows indicate the particular conviction that the T2 court is looking back to. They help illustrate that although courts are seeking to analogize the T1 crime to a federal crime, the $\mathrm{T} 1$ crime was a state law offense. $\mathrm{T} 2$ removal proceedings are in italics since it is those proceedings that are at the heart of this circuit split. 
FIGURE 1.

\author{
Federal \\ Criminal \\ Proceedings \\ Federal \\ Immigration \\ Proceedings
}

State

Criminal

Proceedings
T1

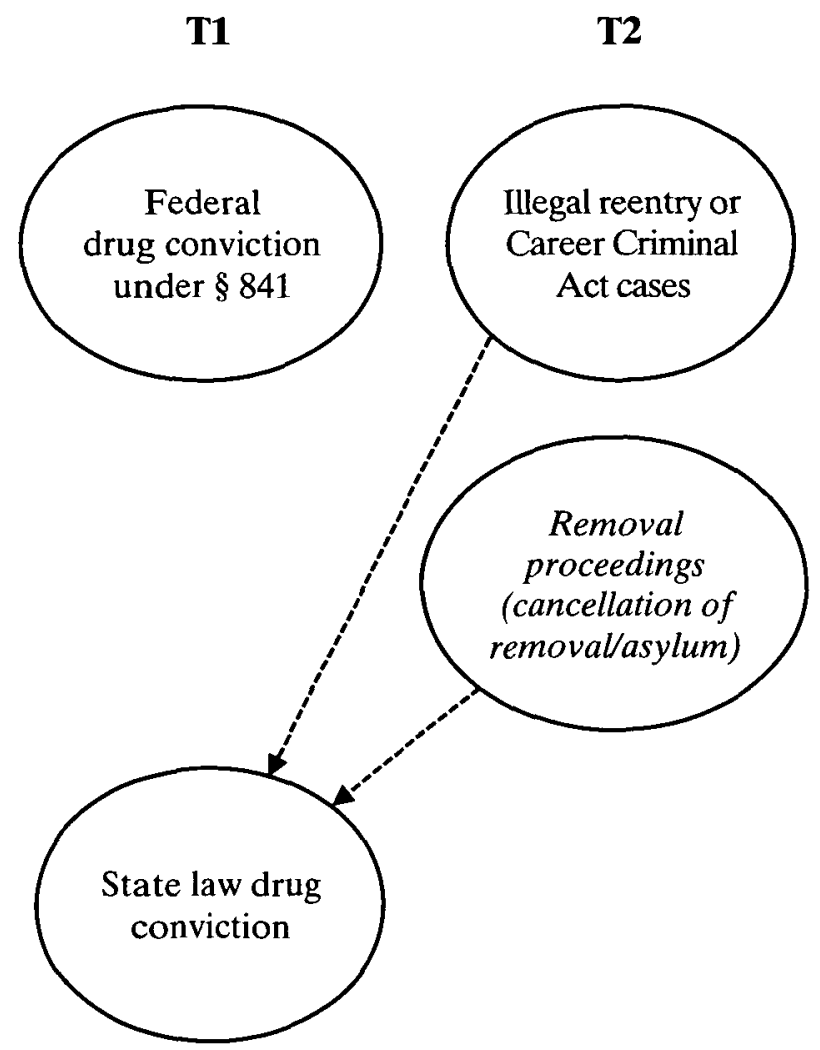

T2

Thus, as a solution, this Comment proposes that, as a baseline presumption for an empty record, the misdemeanor provision should apply. This misdemeanor presumption would assure that immigrants tried in state courts are afforded the proper procedural rights. This means that a noncitizen defendant convicted under a state drug law whose elements correspond to either the felony or the misdemeanor provisions of $\S 841$ would be presumed not to have committed an aggravated felony. This Comment also proposes that, to the extent immigration judges look beyond the elements of the crime to the record of conviction (as Shepard permits), they should limit their inquiries to those facts that were necessarily decided-specifically limited to the reliable sources mentioned in Shepard. ${ }^{160}$ Any contrary

160 The Shepard Court held that the inquiry into the defendant's conviction to determine whether a nongeneric statute

necessarily admitted elements of the generic offense is limited to the terms of the charging document, the terms of a plea agreement or transcript of colloquy between 
approach strays too far from the categorical approach's intentional restriction on collateral fact finding by $\mathrm{T} 2$ courts.

While this solution is similar to the approach of the Third Circuit, it takes into account Supreme Court precedent that had not been decided at the time of the Third Circuit's decision. It also takes a different position with regard to the scope of the factual inquiry that the immigration judges are permitted to undertake, restricting it to only the parts of the record that were truly necessarily decided and tightly limiting intrusive and speculative factual inquiries. Such an approach would likely lead to a different result in Santos. While Santos used the facts recited for the plea bargain that the noncitizen defendant might not have fully agreed to, this approach would construe such ambiguities in the noncitizen's favor, as CarachuriRosendo instructs.

This Part is divided into three sections. Part IV.A argues that the holdings of the courts that have adopted the felony provision as the baseline in immigration proceedings are incompatible with the approach outlined in Lopez and clarified in Carachuri-Rosendo. Part IV.B argues that such an approach is fundamentally flawed because it does not consider that criminal sentencing happens at $\mathrm{T} 1$ and immigration proceedings happen at T2. Part IV.C addresses the unique needs of immigration proceedings and explains why a presumption in favor of the misdemeanor provision, with only limited inquiry into the record of conviction in order to prove that the crime constituted an aggravated felony, is the only workable solution.

\section{A. Respecting Supreme Court Precedent}

The result of the First, Fifth, and Sixth Circuits is at odds with the logic of both Lopez and Carachuri-Rosendo, as well as the underlying principles of the categorical approach for immigration proceedings. Turning to this precedent makes clear that the only way to give full effect to recent Supreme Court precedent on the categorical approach is to hold, as the Second Circuit did, that an empty criminal conviction record must mean that the conviction fits into $§ 841(b)(4)$.

1. The "commonsense conception" of an aggravated felony.

As discussed above, courts have been generally instructed to use a categorical approach when deciding if a state offense meets

judge and defendant in which the factual basis for the plea was confirmed by the defendant, or to some comparable judicial record of this information.

Shepard, 544 US at 26. See also notes 54-57 and accompanying text. 
the elements of a federal offense. ${ }^{161}$ What this approach sought to do was create a uniform approach to defining aggravated felonies that did not depend on the idiosyncrasies of a particular state statute of conviction or the amount of evidence adduced at a particular trial. But in applying the categorical approach, the Court has sought to give meaning to the common sense definitions of the original, enumerated crimes that are at issue.

Recall that the category of aggravated felonies at issue in this split is composed of those crimes involving "illicit trafficking," which is defined by reference to certain felonies under the CSA. ${ }^{163}$ But the crimes that Congress intended to be bars to cancellation of removal in the INA were only those considered illicit trafficking in the everyday meaning of the phrase. ${ }^{164}$ Thus, a noncitizen defendant should have to be convicted of a crime that falls into the actual definition of illicit trafficking before being found to have committed an aggravated felony on that basis.

The Lopez Court was comfortable both expounding a plain meaning of trafficking and applying that plain meaning in determining whether the conduct at issue constituted an aggravated felony. ${ }^{15 s}$ First, as to the definition, the Lopez Court explicitly held that "ordinarily 'trafficking' means some sort of commercial dealing." The Court thus explicitly excluded from the definition of trafficking the precise conduct that is at issue in this Comment-that falling within $\S 841(\mathrm{~b})(4)$ 's mitigating provision, which seems specifically drawn to carve out those who did not commercially deal drugs. And the Court explicitly reiterated that commercial dealing is a necessary element of trafficking in Carachuri-Rosendo ${ }^{\text {67 }}$

Second, the Court applied this plain meaning of trafficking in determining whether the particular noncitizen defendants at issue had committed aggravated felonies, finding they had not. In Lopez, the Court held that this "everyday understanding of 'trafficking' should count for a lot" ${ }^{\text {"16" }}$ and thus held that the particular South Dakota offense that Lopez had been convicted of - "aiding and abetting

\footnotetext{
161 See Part I.B.

162 See, for example, Lopez, 549 US at 53.

163 See notes 20-22 and accompanying text.

164 Consider Lopez, 549 US at 53.

165 See notes 60-66 and accompanying text.

166 Lopez, 549 US at 53.

167 Carachuri-Rosendo, $130 \mathrm{~S} \mathrm{Ct}$ at 2585 (explaining that the "petty simple possession offense is not typically thought of as an 'aggravated felony' or as 'illicit trafficking'" and citing Lopez to reiterate that "trafficking" usually implies commercial dealing), quoting Lopez, 549

168 Lopez, 549 US at 53.
} US at 53. 
another person's possession of cocaine" ${ }^{\text {"169 }}$ - did not correlate to a federal felony under the CSA. ${ }^{170}$ Similarly, in Carachuri-Rosendo, the Court held that the "type of petty simple possession offense" Carachuri-Rosendo was convicted of - possession of one pill- "is not typically thought of as an 'aggravated felony' or as 'illicit trafficking", and thus declined to find him guilty of an aggravated felony. ${ }^{17}$

This logic suggests that the Supreme Court's holdings in Lopez and Carachuri-Rosendo would not permit a finding that an aggravated felony had been committed in an individual case where it was clear that a noncitizen defendant had not engaged in commercial dealing. That is, if it were clear in any given case that a defendant had merely shared marijuana with friends, he could not be held liable for an aggravated felony. This holding itself might counsel against circuit courts adopting a presumption in favor of broadly written state law crimes correlating to $\S 841$ (b)(1)(D), the federal felony provision. This particular logic does not explicitly foreclose such a presumption, however, especially given that in many cases the record of conviction simply might not specify whether the actual conduct committed in fact falls within the federal misdemeanor provision.

Significantly, the Court in both Lopez and Carachuri-Rosendo went one step further by declining to apply the categorical approach in the particular cases at hand and also by implicitly declining to adopt a rule under the categorical approach that would have the effect of frequently converting misdemeanor behavior into an aggravated felony. The Court did not hold that it was entirely impossible for courts, under the categorical approach, to frequently consider misdemeanor conduct as an aggravated felony. The Court did, however, require some plain statement from Congress that it intended that effect before it would reach such a counterintuitive result.

The Lopez Court detailed this logic with great force:

Reading § 924(c) the Government's way, then, would often turn simple possession into trafficking, just what the English language tells us not to expect, and that result makes us very wary of the Government's position. Which is not to deny that the Government might still be right; Humpty Dumpty used a word to mean just what [he chose] it to mean-neither more nor less, and legislatures, too, are free to be unorthodox. Congress can define an aggravated felony of illicit trafficking in an unexpected way.

\footnotetext{
169 Id at 51, citing SD Cod Laws $\S \S 22-42-5,-6-1,-3-3$.

170 See id at 53.

171 Carachuri-Rosendo, $130 \mathrm{~S} \mathrm{Ct}$ at 2585.
} 
But Congress would need to tell us so, and there are good reasons to think it was doing no such thing here. ${ }^{172}$

The Court in Carachuri-Rosendo again echoed this logic, holding that "[b]ecause the English language tells us that ... mere possession of one tablet of Xanax does not constitute 'trafficking,' Lopez instructs us to be doubly wary of the Government's position in this case." "173

The Court's logic here is consistent with what appears to be a rule of lenity that it has adopted with regard to interpretations of criminal statutes in immigration proceedings. As the Court held in Carachuri-Rosendo: "[A]mbiguities in criminal statutes referenced in immigration laws should be construed in the noncitizen's favor."174

This last piece of logic, then, further questions the ability of courts to adopt a baseline federal felony presumption. Under the state statutes of conviction at issue, commercial dealing is not needed for a conviction. Instead, convictions can be for exactly what Congress carved out as a misdemeanor under the CSA - sharing with friends. ${ }^{175}$ As was the case in Lopez, adopting a presumption that a conviction under a broadly written state statute constitutes a felony under $\$ 841(\mathrm{~b})(1)(\mathrm{D})$ would often turn possession of a small amount of marijuana without intent of remuneration into trafficking - "just what the English language tells us not to expect." ${ }^{176}$ That is, even if it could not be shown that in every case the felony presumption would convert misdemeanor conduct into an aggravated felony, it is clear that the presumption will do so in some not insubstantial subset of cases. Lopez and Carachuri-Rosendo suggest that such a result is impermissible under the categorical approach.

Thus, the solution adopted by the First, Fifth, and Sixth Circuits in immigration proceedings is incompatible with the Supreme Court's jurisprudence regarding the categorical approach. The essence of the problem is that these courts would take an activity that simply does not constitute an aggravated felony and would frequently find it to be just that.

Note that this Comment's solution does not call into question the application of $\S 841(\mathrm{~b})(1)(\mathrm{D})$ as the baseline when a federal court sentences an offender under $\S 841(\mathrm{~b})$, in the $\mathrm{T} 1$ criminal sentencing context. The courts that find $\S 841(\mathrm{~b})(1)(\mathrm{D})$ to be the

\footnotetext{
172 Lopez, 549 US at 54-55 (citations and quotation marks omitted).

173 Carachuri-Rosendo, $130 \mathrm{~S} \mathrm{Ct}$ at 2585.

174 Id at 2589.

175 See note 91 and accompanying text.

176 Lopez, 549 at 54.
} 
baseline are simply not directed to use a categorical approach. As the next Section discusses, it is significant that a noncitizen defendant convicted in federal court under the federal statute would have had the opportunity to argue for mitigation at $\mathrm{T} 1$. That is, adopting the $\S 841$ (b)(1)(D) baseline would transform conduct that would have been only a misdemeanor if it had been tried in federal court, into a felony-simply because the case had been tried in a state court. Such concerns simply do not apply to the $\mathrm{T} 1$ criminal sentencing context when the defendant is in federal court.

\section{Respecting procedural protections.}

The Supreme Court's concern for procedural protections in Carachuri-Rosendo-a case with which neither the First, Fifth, nor Sixth Circuit has attempted to reconcile its holdings-also clearly points to a baseline presumption of a misdemeanor.

An animating issue in this circuit split is the extent to which courts view the availability of the $\S 841(\mathrm{~b})(4)$ mitigating provision during the $T 2$ proceeding as an adequate substitute for the particular class of noncitizen defendants that were not given the chance to make the $\S 841$ (b)(4) showing at T1. Recall that, because of the structure of state statutes of conviction and the possibility that state misdemeanor offenses could be characterized as aggravated felonies at the federal level, the $\$ 841$ (b)(4) exception would be first invoked only at $\mathrm{T} 2$, when the noncitizen subject to deportation seeks discretionary immigration relief in the form of cancellation of removal. When this exception is first sought at $\mathrm{T} 2$, the facts and evidence presented in the state case might not provide any insight into whether the noncitizen defendant would have qualified for the exception at T1.

As recounted above, courts applying the felony presumption have fixated on the procedural rights surrounding the imposition of the mitigating provision at a $\mathrm{T} 1$ federal trial. That is, in considering whether it is permissible to force noncitizen defendants to prove mitigation, these courts have basically reduced the question to whether, at $\mathrm{T} 1$, it would have been permissible to require a federal criminal defendant to prove his eligibility for mitigation. ${ }^{1 m}$ After reviewing Apprendi-which undisputedly does not create a problem with requiring a criminal defendant to prove his eligibility for mitigation at a T1 criminal sentencing-these courts have found no hurdle to requiring a noncitizen, at $\mathrm{T} 2$, to prove this same mitigation. ${ }^{178}$ To put

177 See notes 118-26 and accompanying text.

178 See notes $100-03$ and accompanying text. 
it another way, none of the courts applying the felony provision presumption has found any prejudice in requiring the noncitizen defendant to prove his eligibility for mitigation at $\mathrm{T} 2$, even though at $\mathrm{T} 1$ he was never asked (and would have had no incentive) to collect or present any such evidence.

But this result entirely belies the logic of the Supreme Court in Carachuri-Rosendo. The crux of the Carachuri-Rosendo Court's holding was that there is a vast difference between providing a procedural right at T1 (in a criminal defendant's original trial) and waiting until T2 (in a collateral proceeding) to satisfy that procedural right. ${ }^{179}$ Specifically, with a recidivist conviction, the Court noted that "[n]otice, plus an opportunity to challenge the validity of the prior conviction used to enhance the current conviction, [under 21 USC] $\S \S 851(\mathrm{~b})-(\mathrm{c})$, are mandatory prerequisites to obtaining a punishment based on the fact of a prior conviction." ernment would dismiss these procedures as meaningless, so long as they may be satisfied during the immigration proceeding," the Court found that "these procedural requirements have great practical significance with respect to the conviction itself and are integral to the structure and design of our drug laws." ${ }^{\prime 11}$

In this circuit split, while there is no statute granting a procedural right of notice, there is a procedural right of significant importance involved - the right to gather and present evidence for mitigation. In a federal $\mathrm{T} 1$ proceeding, each of the noncitizen defendants would have the opportunity to argue for mitigation - to argue that his crime was only for a small amount of marijuana and was not for remuneration. Had he been able to meet this burden, he would have been convicted of a misdemeanor pursuant to $\S 841$ (b)(4) and not an aggravated felony.

By using $\$ 841(\mathrm{~b})(1)(\mathrm{D})$ as the baseline, the noncitizen defendant is thus being denied procedural rights he would have had if he had been charged under federal law. As the Carachuri-Rosendo Court held, one cannot "dismiss these procedures as meaningless" simply because "they may be satisfied during the immigration proceeding." "182 That is to say, the Court flatly rejects the notion that merely providing the same procedural right at $\mathrm{T} 2$ as a replacement for not having it at $\mathrm{T} 1$ suffices to satisfy the respect for the procedural requirements that the categorical approach requires. This result

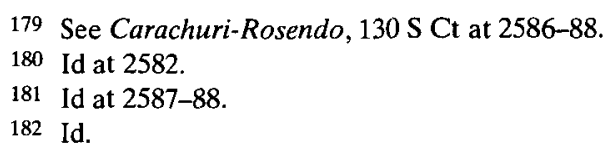


makes sense: the federal government should not get a second shot to cure defects from the first trial that might result in a felony conviction where a state only obtained a misdemeanor conviction (nor should the defendant get a second chance to cure defects that might result in the imposition of a less serious sentence).

And, of course, even if the Carachuri-Rosendo Court had not explicitly rejected the possibility of simply providing the T1 procedural rights to the noncitizen defendant at $\mathrm{T} 2$, it does not follow that merely providing the noncitizen defendant the ability to prove his eligibility for mitigation at $\mathrm{T} 2$ is a satisfactory substitute for his ability to have done so at $\mathrm{T} 1$. This prejudice to noncitizens-being forced to wait until $\mathrm{T} 2$ to prove their eligibility for the misdemeanor provision-is explored below.

To address any remaining uncertainty, Carachuri-Rosendo held that "ambiguities in criminal statutes referenced in immigration laws should be construed in the noncitizen's favor." ${ }^{\text {"183 }}$ Section 841 (b) is unarguably ambiguous - especially considering the underlying circuit splits in criminal sentencing-and, as such, it must be construed in the noncitizen defendant's favor in immigration proceedings. That is, the misdemeanor provision should be the baseline presumption.

3. Fully rejecting the "hypothetical federal felony" approach.

In the end, the First, Fifth, and Sixth Circuits' premise that a noncitizen defendant bears the burden of proof ignores the fact that courts at $\mathrm{T} 2$ will not be permitted to consider outside evidence of his conduct according to the principles in Uhl, Lopez, and CarachuriRosendo. The direct holding of Carachuri-Rosendo is that a court at T2 "cannot, ex post, enhance the state offense of record just because facts known to it would have authorized a greater penalty under either state or federal law." ${ }^{2}$ That does not directly apply to what the baseline should be because at T2 it is the noncitizen defendant who would be required to produce this evidence, not the prosecution. The underlying rationales for this holding do directly apply in the immigration context, however, binding the noncitizen defendant and the prosecution alike.

A key rationale for Carachuri-Rosendo's holding was that, following the Lopez rule, the question is not whether the defendant's conduct matches up to any particular hypothetical federal felony, but whether the conduct on which the defendant's conviction was based

183 Carachuri-Rosendo, $130 \mathrm{~S} \mathrm{Ct}$ at 2589.

184 Id at 2586. 
would have - and could have - been punishable as a federal felony. ${ }^{185}$ On the other hand, the hypothetical federal felony approach the Government was arguing for would have allowed a court to look beyond the conduct squarely considered by the T1 court. If CarachuriRosendo had been sentenced in a federal court, "[i]t is quite unlikely that the 'conduct' that gave rise to Carachuri-Rosendo's conviction would have been punished as a felony."1\%6 The conduct at issue in his $\mathrm{T} 1$ trial was only the possession of a single prescription pill: the T1 court had never considered any enhancement based on prior convictions.

For a noncitizen defendant, possession of a small amount of marijuana with no intent of receiving remuneration likely would not be punished as a felony were the conviction in a federal court. As a defendant in federal court, he could have successfully argued for mitigation under $\$ 841$ (b)(4). On the other hand, his overall conduct is at least potentially or hypothetically punishable as a felony. What Carachuri-Rosendo clarified is that translating a state law crime into a more severe federal crime based on such a hypothetical inquiry is simply inappropriate.

Equally important in Carachuri-Rosendo was the Court's holding that the government cannot come back in at T2 and present evidence that could have increased the $\mathrm{T} 1$ conviction to an aggravated felony. The Court noted that "[i]ndisputably, Carachuri-Rosendo's record of conviction contains no finding of the fact of his prior drug offense... [ [A T2 court] cannot, ex post, enhance the state offense of record just because facts known to it would have authorized a greater penalty under either state or federal law." 187 The basic idea is that the existence of new evidence that increases the penalty for a crime cannot be submitted at $\mathrm{T} 2$ since it had not been necessarily decided at $\mathrm{T} 1$.

This idea hearkens back to the very origins of the categorical approach: $U h l$ highlighted this limitation on the introduction of new evidence at the $\mathrm{T} 2$ proceeding and saw the limitation to the original elements of conviction as a crucial aspect of the categorical ap proach. And, importantly, the $U h l$ court saw this restriction as applying to both the Government and the noncitizen defendant. ${ }^{188}$ The court explicitly rejected the idea that the noncitizen defendant should have the opportunity (or burden) during a $\mathrm{T} 2$ proceeding to show facts that depart from his actual T1 convictions:

\footnotetext{
185 Id at 2586-87.

186 Id at 2589.

187 Carachuri-Rosendo, $130 \mathrm{~S} \mathrm{Ct}$ at 2586.

$188 \mathrm{Uhl}, 210 \mathrm{~F}$ at $862-63$.
} 
[T]he rule which confines the proof of the nature of the offense to the judgment is clearly in the interest of a uniform and efficient administration of the law and in the interest of the immigration officials as well, for if they may examine the testimony on the trial to determine the character of the offense, so may the immigrant. ${ }^{189}$

Uhl, Lopez, and Carachuri-Rosendo, taken together, demonstrate that in this circuit split, neither the Government nor the noncitizen defendant can bring in outside evidence regarding whether the actual conduct would have fit into the federal misdemeanor provision or the federal felony provision. The very idea of bringing in such outside evidence is inherently incompatible with the categorical approach. Thus, in immigration proceedings, with regard to prior crimes, there is no real "burden of proof" for anyone to bear, but merely a presumption that, by design, is largely unrebuttable. Such a conclusion renders illusory the argument that a rebuttable felony presumption could be easily applied to the immigration context.

\section{B. Consistency in the Law}

Admittedly, the First, Fifth, and Sixth Circuits' holdings are animated by a desire to assure consistency with the way a $\mathrm{T} 1$ federal criminal sentencing operates. ${ }^{1 * 0}$ But this approach is misguided; it does not justify deviating from Supreme Court precedent that suggests substantial differences between the initial criminal sentencing context and the reevaluation, at T2, of that criminal sentencing (especially given that this precedent squarely rejects the fiction that there was an initial federal criminal sentencing to begin with ${ }^{191}$ ). Admittedly, the law of federal sentencing is complex, and judges might understandably desire to treat $\mathrm{T} 1$ and $\mathrm{T} 2$ sentencing decisions as consistently as possible. But, in the immigration context, such consistency simply belies the fundamentally different positions of the T1 criminal sentencing judge and the $\mathrm{T} 2$ immigration judge.

Further, these courts have ignored the fact that the felony presumption simply cannot apply in all circumstances-and thus that there must, at least sometimes, be some deviation from the way that federal criminal law is interpreted to apply at a $\mathrm{T} 1$ federal criminal

189 Id (disregarding the evidence in the record that the defendant made libelous comments about the Queen's children and admiral's daughter and instead focusing on the fact that libel is not necessarily a crime that demonstrates moral turpitude).

190 See Part III.A.

191 See note 78 and accompanying text. 
sentencing. As this Part establishes, when the T2 proceeding that is evaluating a prior state law drug conviction is a federal criminal sentencing hearing, applying a felony presumption would run afoul of the Supreme Court's precedent in Apprendi, Shepard, and Taylor. Since illegal reentry criminal sentencing falls into that category, courts must choose to make immigration proceedings consistent with either T1 or T2 proceedings - either way, unless $\S 841(\mathrm{~b})(4)$ becomes the baseline in all cases, there is going to be some inconsistency.

FIGURE 2.

\section{This Comment}

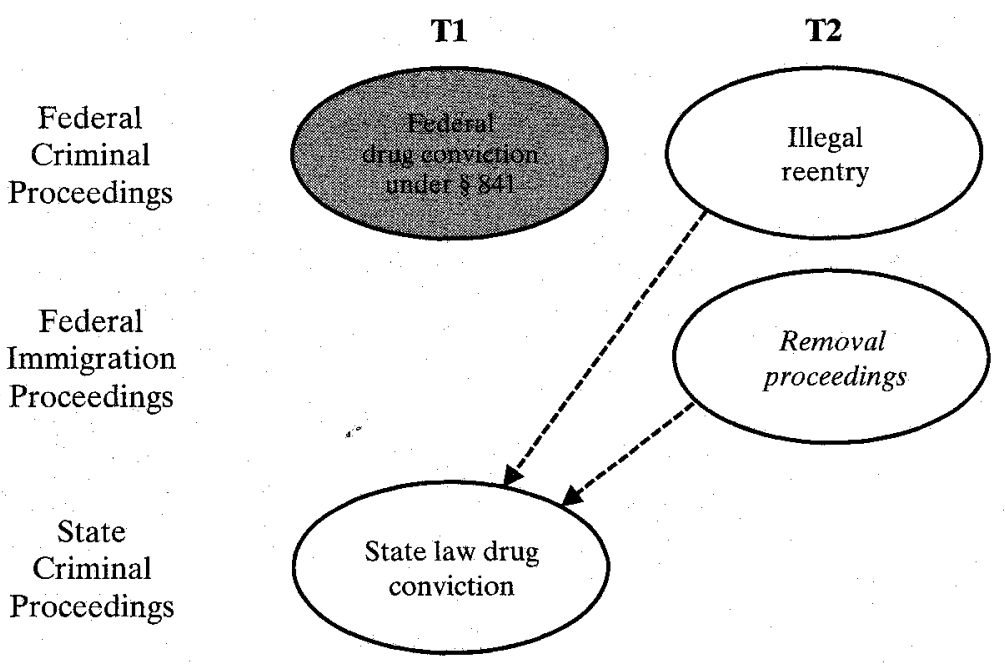

First, Fifth, and Sixth Circuits

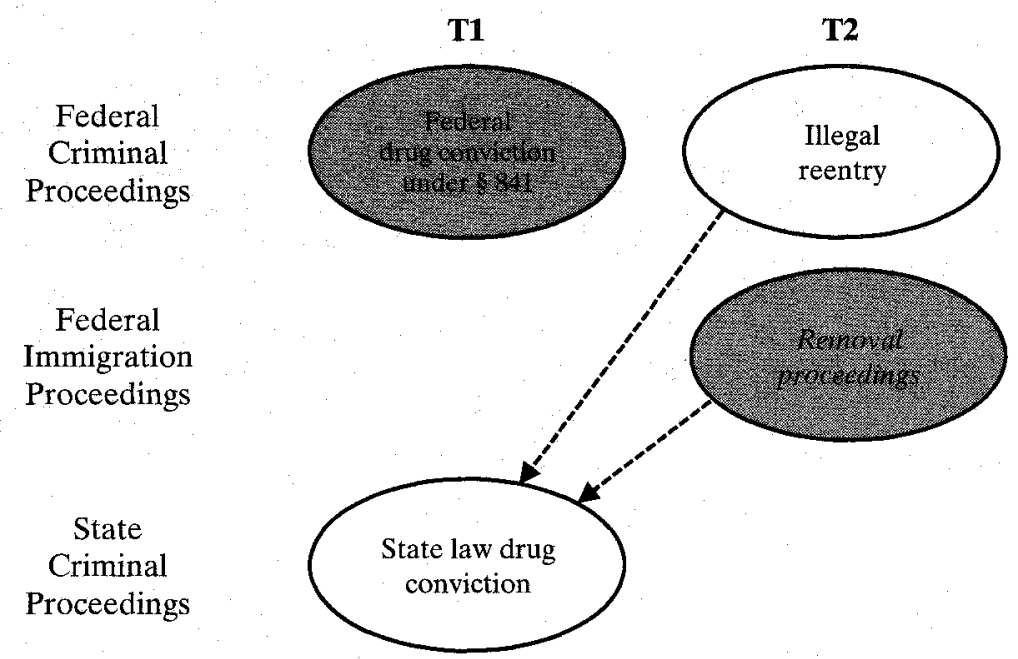


Figure 2 illustrates the two inconsistencies at issue by shading the proceedings in which either this Comment or the First, Fifth, and Sixth Circuits would apply the felony presumption. Note that the felony presumption is never applied at $\mathrm{T} 1$ in state court proceedings because it is the very fact that such state laws do not have such a mitigating provision that resulted in this split in the first place.

Given this inevitable lack of uniformity, the only question is which inconsistency makes more sense. The first option is to allow inconsistency between the $\mathrm{T} 1 \mathrm{criminal}$ sentencing and the $\mathrm{T} 2 \mathrm{immi}-$ gration proceeding. Alternatively, courts might prefer inconsistency between the two $\mathrm{T} 2$ contexts in which prior state law drug convictions are reviewed-immigration proceedings and illegal reentry cases. But, importantly, one option must be chosen-there is no solution that would allow consistency across all dimensions (unless, of course, circuits begin reading $\$ 841$ (b)(4) as the baseline in all proceedings, but such a solution is beyond the scope of this Comment). This Comment argues that it is far more logical to draw the line between $\mathrm{T} 1$ cases and $\mathrm{T} 2$ cases than to treat the two $\mathrm{T} 2$ contexts differently.

\section{Illegal reentry: Apprendi concerns.}

In illegal reentry cases interpreting prior state law drug convictions under $\$ 841(b)(4)$ - which are entirely independent from immigration proceedings - courts are bound by Shepard and Taylor to use a categorical approach and by Apprendi to apply the misdemeanor presumption within that approach.

Illegal reentry is a federal criminal offense that is triggered when a noncitizen is caught reentering, or found in the United States, after he has "been denied admission, excluded, deported, or removed or has departed the United States while an order of exclusion, deportation, or removal is outstanding." dividual convicted of illegal reentry, however, is highly dependent on his prior criminal history. A defendant convicted of illegal reentry but who does not have a prior criminal record could receive maximum imprisonment of two years. ${ }^{193} \mathrm{~A}$ defendant with a prior criminal conviction, but without an aggravated felony conviction, ${ }^{194}$ could re-

1928 USC $\S 1326(\mathrm{a})(1)$.

193 See 8 USC \& 1326(a).

194 Illegal reentry cases refer to the same provision in the INA for defining "aggravated felony" as is used in all other immigration proceedings. See, for example, Simpson, 319 F3d at 84. See also 8 USC $\S 1101(a)(43)$. 
ceive up to ten years. ${ }^{195}$ But a defendant with a prior aggravated felony conviction could receive up to twenty years in prison. ${ }^{106}$ Therefore, as in the Shepard and Taylor line of cases, and in the circuit split that is the focus of this Comment, a judge confronting this provision will be assessing at $\mathrm{T} 2$ a prior state law drug conviction from $\mathrm{T} 1$. Thus, the same question arises about whether to assume that the state law drug conviction corresponds to the misdemeanor or felony provision in $\$ 841(\mathrm{~b})$.

The only case to clearly confront the issue of whether the felony or misdemeanor presumption applies in illegal reentry cases is Simpson, a Second Circuit case. Without considering a categorical approach, and with little analysis of the issue, the Simpson court simply affirmed the holding of the district court upon finding that the noncitizen defendant's crimes "would have been punishable as a felony under the CSA" and thus were aggravated felonies. ${ }^{197}$ Of course, the Second Circuit later found that this holding was not binding when interpreting prior, state law drug convictions in immigration proceedings since the court had not applied the categorical approach in illegal reentry cases. ${ }^{198}$ This Comment argues that while the Second Circuit came to the right conclusion with regard to the treatment of prior, state law drug convictions for immigration proceedings, it came to the wrong conclusion for illegal reentry by failing to realize that the misdemeanor presumption is compelled in illegal reentry cases.

A core holding in Apprendi is that while the fact of a prior conviction does not need to be proved beyond a reasonable doubt, any other fact that increases the penalty for a crime beyond the statutory maximum must be submitted to a jury and proved beyond a reasonable doubt. ${ }^{199}$ In illegal reentry cases, a court's finding that the conduct in a T1 state law drug conviction is equivalent to a felony under $\S 841$ (b)(1)(D) - as opposed to a misdemeanor under $\S 841$ (b)(4)raises the potential statutory maximum to ten years, ${ }^{200}$ thus implicating Apprendi to the extent that this turns on a factual determination. And, indeed, the difference between the application of these two provisions is a factual one, depending specifically on the amount of marijuana and whether the exchange was for remuneration. Yet,

\footnotetext{
195 See 8 USC $\$ 1326(b)(1)$.

196 See 8 USC $\S \S 1101(a)(43), 1326(b)(2)$.

197 Simpson, 319 F3d at 85-86.

198 See Martinez, 551 F3d at 121.

199 Apprendi, 530 US at 491-92.

200 See 8 USC $\S 1326(b)$ (1).
} 
contrary to Apprendi, applying the felony presumption does not allow these facts to be submitted to a jury and proved beyond a reasonable doubt. The conclusion is thus that Apprendi mandates the application of the misdemeanor presumption when interpreting prior, state law drug convictions. ${ }^{201}$

This might seem like a counterintuitive result. All courts agree that applying the felony presumption during a $\mathrm{T} 1$ federal criminal sentencing does not violate Apprendi. One might wonder, then, how applying that same presumption at $\mathrm{T} 2$ does so. The answer stems from the differences in the statutory schemes to which Apprendi is being applied. In the T1 context, Apprendi operates during sentencing to protect an individual who has been convicted of a federal drug crime. Given the unique structure of $\S 841(\mathrm{~b})(4)$ 's mitigating provision, courts presume a baseline of a felony conviction (thus, Appren$d i$ does not offer very much protection in this context). But in the T2 illegal reentry context, it is the illegal reentry provision-not $\S 841(b)$ - that determines the baseline for the Apprendi analysis because it is this provision that provides the significant sentencing enhancement for prior crimes. And, unlike $\S 841$ (b), Apprendi requires that, in interpreting the facts predicate to those sentencing enhancements, the predicate facts be charged in the indictment, submitted to a jury, and found to be true beyond a reasonable doubt. ${ }^{212}$ Thus, whatever might be required in an initial federal criminal sentencing does not necessarily suffice at $\mathrm{T} 2$. After all, the initial federal criminal sentencing is only an analogy that is useful to courts working through the categorical approach. Ultimately, it is a prior state law drug conviction that is actually at issue in $\mathrm{T} 2$.

The Shepard-Taylor precedent, which also evaluates a T1 state law conviction's effect on sentencing, supports this result. Giving weight to Apprendi, a plurality of the Court in Shepard explicitly held that any factual decisions-including those relating to the $\mathrm{T} 1$ conviction - that could increase the "ceiling of a potential sentence" would need to be submitted to the jury. ${ }^{213}$ In Shepard, this reasoning meant that "the scope of judicial factfinding on the disputed generic character of a prior plea [must be limited], just as Taylor constrained judicial findings about the generic implication of a jury's verdict." ${ }^{214}$ As a result, a plurality in Shepard held that a judge may only look at what was necessarily decided-and may not evaluate potential factual dis-

\footnotetext{
201 See Apprendi, 530 US at $492-94$.

202 Id at 490.

203 Shepard, 544 US at 25 (Souter) (plurality).

204 Id at 25-26.
} 
putes ${ }^{205}$ Such reasoning has a profound implication for illegal reentry cases-essentially dictating the outcome of the presumption for purposes of $\mathrm{T} 2$ criminal sentencing. By foreclosing judges from engaging in factual determinations regarding whether a state conviction was necessarily an aggravated felony-because that would increase the ceiling of a potential illegal reentry sentence-such reasoning precludes the adoption of the felony presumption in illegal reentry cases.

Thus, layering the categorical approach on illegal reentry cases shows that judges cannot simply adopt a procedure that requires illegal reentry defendants at $\mathrm{T} 2$ to prove that their prior conduct comported with the federal misdemeanor. The only constitutionally permissible result, under Apprendi, is a presumption that the conduct would have been punishable as a misdemeanor under the CSA.

2. $\mathrm{T} 1$ criminal sentencing inconsistencies.

Thus, while circuit judges are understandably concerned about creating inconsistency in the law-for example, where $\S 841(\mathrm{~b})(4)$ will be seen as a mitigating provision in criminal sentencing, but as the baseline provision in immigration proceedings-some inconsistency is inevitable given the analysis Apprendi and Shepard dictate for illegal reentry. Illegal reentry cases, at $T 2$, must apply a baseline of $\S 841$ (b)(4) when determining if a T1 crime is an aggravated felony. But, in T1 criminal sentencing a baseline of $\S 841(b)(1)(D)$ has been the uniform approach.

This Comment suggests that the inconsistency between T1 and $\mathrm{T} 2$ proceedings is both inevitable and desirable, especially when contrasted with the differences between $\mathrm{T} 1$ criminal sentencing proceedings and $\mathrm{T} 2$ immigration proceedings. As an initial matter, the equivalence between $\mathrm{T} 1$ criminal sentencings and $\mathrm{T} 2$ immigration proceedings does not take into account the different functions of $\mathrm{T} 1$ criminal sentencings and $\mathrm{T} 2$ immigration proceedings. In $\mathrm{T} 1 \mathrm{criminal}$ sentencings, judges are authorized to consider facts that are not elements of a crime but could be used for mitigation. Immigration judges, however - far removed from the criminal proceedings and under long-standing traditions of avoiding fact-finding expeditions altogether-are largely unable to hear testimony regarding mitigation at $\mathrm{T} 2 .{ }^{216}$ Under the categorical approach of Lopez, immigration judges

205 Id at 26.

206 The immigration judge could hear mitigation evidence to the extent that facts were necessarily decided in the record of conviction. See Taylor, 495 US at 602. 
are instructed to consider the facts regarding the conduct of the defendant that have necessarily been decided by criminal courts. ${ }^{20}$ Immigration judges are generally not permitted to consider new evidence-and certainly not new evidence regarding a prior criminal conviction.

This difference in the role of the two courts is highlighted by the general differences between criminal and immigration courts. Whereas procedures in federal district courts are set up to ensure the numerous procedural rights that are afforded to a defendant by the Constitution, immigration proceedings are not set up to provide the same type of rights because immigrants have traditionally been viewed as enjoying far fewer rights than a criminal defendant. ${ }^{20 *}$ This is perhaps underscored by the fact that, in immigration proceedings, the Federal Rules of Evidence-which guarantee such fundamental protections as the rule against hearsay and which also embody a number of constitutional due process and criminal procedural protections ${ }^{211}-$ do not apply to limit the type of evidence that may be presented to an immigration judge. ${ }^{210}$ Consider whether, as a matter of institutional competence, it is desirable for immigration judges to be required to master the intricacies of Confrontation Clause or exclusionary rule jurisprudence. Immigration proceedings are, appropriately, structured entirely differently than those dealing with criminal defendants facing sentencing, where judges are still able to consider the facts of the case and determine whether they fit into $\S 841$ (b)(4).

And, of course, there are other differences between the T1 and $\mathrm{T} 2$ contexts that suggest merely providing the right to prove mitigation at T2 does not provide a meaningful opportunity for the noncitizen defendant to prove that he has only committed a misdemeanor. Most obviously, there is the fact that so much time will have passed since the $\mathrm{T} 1$ conviction. Given the passage of time, finding evidence as to the nature of the crime will become exponentially more difficult: Evidence grows stale and witnesses might become scarce. While

207 See Lopez, 549 US at 53-54.

208 See, for example, Jim Rosenfeld, Deportation Proceedings and Due Process of Law, 26 Colum Hum Rts L Rev 713, 739 (1995) ("[A]lthough it is clear that aliens involved in deportation proceedings are entitled to procedural due process, it is not at all clear what this entails in any particular context.").

209 See, for example, FRE 801(d)(2)(E) (limiting testimony by coconspirators and setting conditions precedent before such testimony can be admitted to satisfy Confrontation Clause concerns); FRE 801(d)(2)(E), Advisory Committee Notes to the 1997 Amendments. See also Bourjaily v United States, 483 US 171, 182 (1987).

210 See Matter of $D-R-, 25$ I \& N Dec 445, 457-58 (BIA 2011). 
a criminal defendant at $\mathrm{T} 1$ would be entitled to counsel, no such right is guaranteed in immigration proceedings. ${ }^{211}$ Further, given the current landscape of immigration enforcement, the noncitizen is significantly more likely to be detained-and thus completely unable to aid in his own defense - than a criminal defendant, who, under the provisions of the Bail Reform Act of $1984,{ }^{212}$ would likely be free pending trial. ${ }^{213}$

Thus, inconsistencies between the $\mathrm{T} 1$ criminal sentencing context and T2 immigration proceeding are both inevitable and desirable. What these differences suggest, however, is that there are significant doubts about whether the ability to prove mitigation at $\mathrm{T} 2$ adequately substitutes for having not been provided that right at $\mathrm{T} 1$. Such doubts call into question the felony presumption, which hangs its hat on the essentially illusory ability of the noncitizen defendant to prove mitigation at $\mathrm{T} 2$.

\section{The Needs of Immigration Proceedings: Why Courts Use the Categorical Approach}

With all of the complexities that this circuit split unearths, to get a truly workable solution, one must not forget the unique procedures and results of immigration proceedings. Respect for the underlying policy considerations at the heart of the categorical approach in immigration proceedings - as first highlighted in $U h l^{14}$ and as followed since ${ }^{215}$-mandates that the misdemeanor mitigation presumption apply in immigration proceedings.

A key goal of the categorical approach has always been the uniform administration of the law. ${ }^{216}$ It follows that to achieve this goal, immigration judges must look at the state offense in terms of the elements or necessary conduct for the offense, as opposed to the actual conduct of the individual defendant. As the Uhl court observed, to prevent injustice, the law must be uniformly administered "upon broad general lines." ${ }^{217}$ In other words, if two noncitizens are convicted of the same crime, one should not be excluded from the country be-

211 See Aguilera-Enriquez v INS, 516 F2d 565, 568-69 (6th Cir 1975).

212 Comprehensive Crime Control Act of $1984 \S \S 202-03$, Pub L No 98-473, 98 Stat 1837, 1976 , codified at 18 USC $\S \S 3141-51$.

213 See 18 USC $\$ 3142(\mathrm{e})$. See also Anil Kalhan, Rethinking Immigration Detention, 110 Colum L Rev Sidebar 42, 45-46 (July 21, 2010), online at http://papers.ssrn.com/sol3/ papers.cfm?abstract_id=1556867 (visited Sept 23, 2012).

214 See notes 24-35 and accompanying text.

215 See notes 36-39 and accompanying text.

$216 \mathrm{Uhl}, 210 \mathrm{~F}$ at 862.

217 Id at $862-63$. 
cause his trial was more involved and included evidence suggesting moral turpitude, while the other's trial record was empty (if, for example, he pleaded guilty). This Comment's solution, then, allows a defendant with minimal facts on the record to be treated the same as one with a complete record-especially given that the two defendants could have engaged in identical conduct.

Another key goal of the categorical approach is avoiding disparate treatment, and thus promoting an ethical government. ${ }^{218}$ Given that the noncitizen defendant likely will not-and could not-have a meaningful opportunity to present mitigation evidence in his $\mathrm{T} 2$ proceeding, it would be fundamentally unfair for an immigrant to be locked into an aggravated felony determination under $\S 841$ (b)(1)(D), when he could have been able to prove the applicability of $\S 841(b)(4)$ were he given the chance at T1.

Finally, the goal of efficient adjudication in immigration proceedings, and the fact that immigration judges serve an administrative role not involving collateral fact finding ${ }^{219}$ leads to a presumption of a misdemeanor. If immigration judges were to look deep into the $\mathrm{T} 1$ record of conviction, immigration adjudication would become a much longer process. This factor cuts against the test used by the Third Circuit, which allows for a fairly extensive factual inquiry into the record. ${ }^{220}$ Further, any in-between approach-like the Third Circuit's - which goes case by case, is simply contrary to the role of the immigration judge. While there might be evidence a noncitizen defendant could introduce, it is not the immigration judge's role to determine the reliability of $\mathrm{T} 1$ evidence at $\mathrm{T} 2$. The immigration proceeding should not become an ex post criminal hearing-the presumption must be a misdemeanor and this presumption should only be rebutted when the $\mathrm{T} 1$ trial record clearly shows that the defendant's conduct was not a misdemeanor.

An equitable and efficient system requires a solution that is clear cut and easy to follow for both the noncitizens and the immigration system administrators. Making law more complicated than it needs to be keeps these noncitizen defendants in limbo for longer than necessary-during which time they are often in mandatory detention-while complicated legal issues are repeatedly appealed. Further, noncitizen defendants in immigration proceedings are not entitled to an attorney, and they do not always have a firm grasp of basic English, let alone of the complexities of the immigration laws.

\footnotetext{
218 See id at 862 .

219 See id at 863.

220 See Santos, 352 Fed Appx at 744.
} 
Thus, the idea of noncitizen defendants finding and effectively presenting evidence from past crimes, or otherwise proving at $\mathrm{T} 2$ that they would have fit into the misdemeanor provision, is simply fantasy, both in terms of practicality and legality.

Immigration administrators would also benefit from this clearcut rule. Immigration prosecutors should know whether fighting an issue of law is worth their time and should not have to step into the role of the criminal prosecutor-evaluating and attempting to discredit any evidence the noncitizen defendant might bring. The added costs of a confusing law is clear even when only considering the housing costs of those mandatorily detained. ${ }^{21}$

These considerations all lead to a solution that both is simple and gives the immigrant the benefit of the doubt when the evidence is unclear. In light of these considerations the solution must be that on an empty criminal trial record a court must presume the noncitizen defendant's conduct would have fit into the $\$ 841(\mathrm{~b})(4)$ misdemeanor provision. To the extent that the record clearly indicates that the crime was for remuneration or for a large quantity of drugs, this information should not be ignored. In other words, the presumption is rebuttable, but rebuttal is appropriate only where the evidence is clear. Given that the current immigration system is already exceedingly complicated, this solution is the only workable one.

\section{CONCLUSION}

Deportation is a drastic measure, and cancellation of removal is one of the last forms of relief available for noncitizens who have built lives in United States and lived here for years. Thus, no one should be barred from applying for cancellation of removal unless he has clearly committed an aggravated felony. The confusion in this area of the law is, no doubt, immense. But the solution itself need not be complicated. The key difference between $\S 841$ (b)(4) criminal sentencings and $\S 841(\mathrm{~b})(4)$ immigration proceedings is temporal. As Supreme Court precedent makes clear, immigration courts acting at $\mathrm{T} 2$ are to use a categorical approach when considering $\mathrm{T} 1$ criminal convictions. This is, and should be, a different analysis than criminal

221 The National Immigrant Justice Center reports that "[t]he administration's fiscal year 2012 budget requests more than $\$ 2$ billion - a record high-to maintain 33,400 immigration detention beds daily. Between fiscal years 2002 and 2010, ICE's overall budget more than doubled to $\$ 5.74$ billion." National Immigration Justice Center and Midwest Coalition for Human Rights, Not Too Late for Reform: A Call for President Obama to Close Failed Immigration Detention Facilities, Halt Costly Privatization \& Restore Basic Human Rights; A Report from the Midwest 10 (Dec 2011), online at http://www.scribd.com/doc/76226036/NIJC-MCHR-Not-Too -Late-for-Reform-Report (visited Sept 23, 2012). 
sentencing courts use when sentencing an individual in the first instance. Supreme Court precedent mandates that the $\S 841(\mathrm{~b})(4)$ presumption should be in the noncitizen defendant's favor. The solution must be clean and easy and, lest we deport our neighbors and community members unnecessarily, the only workable solution is to presume the lowest possible version of an offense, a misdemeanor. 
Fid 